\title{
Does the expansion of the species' breeding range also involve the establishment of new migratory routes and new wintering ranges? The case of the citrine wagtail Motacilla citreola (Pallas, 1776)
}

\author{
Flavio Ferlini ${ }^{1 *}$, Klaus Malling Olsen ${ }^{2}$
}

\begin{abstract}
From the second half of the $20^{\text {th }}$ century, some Asian or Eastern European species expanded their breeding range westward. These include red-flanked bluetail Tarsiger cyanurus, black-headed bunting Emberiza melanocephala, common rosefinch Carpodacus erythrinus, and citrine wagtail Motacilla citreola. All of these species are long-range migratory species that historically have their own wintering ranges concentrated in Southern Asia. Although migratory behavior is mainly controlled by genetic factors, there is evidence of a high degree of flexibility and adaptability. Therefore, in the event of specific environmental changes, the genetic basis for a rapid and diverse microevolutionary development that affects the future migration patterns of birds is already in place. Possible adaptations also include changes to migratory directions and the choice of new and closer winter quarters. It is therefore prudent to ask whether the long-range migratory species that have expanded their breeding range westward in Europe have also established new migration routes and wintering ranges. This research shows that over the last few decades, the wintering area of Motacilla citreola has expanded westwards, including significantly the Middle East and, to a lesser extent, Africa and Europe. Especially in the activation of the most western routes, a fundamental role was played by the phenomenon of post-fledging dispersal, manifested by young who, as also observed in other Asian passerines (e.g., Pallas's warbler Phylloscopus proregulus, yellow-browed warbler Phylloscopus inornatus, pine bunting Emberiza leucocephalos), in autumn moved in different directions than the typical migratory route of their species. The Middle East and the neighboring Horn of Africa are progressively increasing in relevance as an additional area for the wintering of the species as a whole. Similarly, if in Europe the expansion of the breeding range towards the west continues in the future, West Africa, reached through Gibraltar, could become important as additional wintering ranges. In analogy with what is being observed for the western yellow wagtail Motacilla flava, Europe itself is also becoming part of the wintering range of the species. In fact, there is an increase in cases of wintering not only in the south of the continent, but there is also a progression towards the north.
\end{abstract}

Keywords: Motacilla citreola, citrine wagtail, breeding range expansion, wintering range expansion, migratory route, post-fledging dispersal, reverse migration.

Società Italiana di Scienze Naturali, Corso Venezia 55, 20121 Milano, Italia.

${ }^{2}$ Smørumvej 221, DK 2700 Brønshøj, Denmark.

* Corresponding author: flavio.ferlini@unipv.it

(C) 2022 Flavio Ferlini, Klaus Malling Olsen

Received for publication: 2 May 2021

Accepted for publication: 19 August 2021

Online publication: 20 May 2022
Riassunto - L'ampliamento dell'areale riproduttivo della specie comporta anche l'instaurarsi di nuove rotte migratorie e nuove aree di svernamento? Il caso della cutrettola testagialla orientale Motacilla citreola (Pallas, 1776).

Dalla seconda metà del XX secolo, alcune specie asiatiche o dell'Europa orientale hanno ampliato il proprio areale riproduttivo verso occidente. Tra queste ricordiamo il codazzurro Tarsiger cyanurus, lo zigolo capinero Emberiza melanocephala, il ciuffolotto scarlatto Carpodacus erythrinus e la cutrettola testagialla orientale Motacilla citreola. Tutte queste specie sono migratrici a lungo raggio che storicamente hanno i propri areali di svernamento concentrati nell'Asia meridionale. Sebbene il comportamento migratorio sia controllato principalmente da fattori genetici, vi sono prove di un alto grado di flessibilità e adattabilità. Pertanto, in caso di specifici cambiamenti ambientali, è già presente la base genetica per uno sviluppo microevolutivo rapido e diversificato che influisce sui futuri modelli di migrazione degli uccelli. Possibili adattamenti includono anche modifiche alle direzioni migratorie e la scelta di nuove e più vicine aree di svernamento. È quindi legittimo chiedersi se le specie migratrici a lungo raggio che hanno ampliato il loro areale di riproduzione verso ovest in Europa abbiano anche stabilito nuove rotte migratorie e nuove aree di svernamento. Questa ricerca evidenzia che nel corso degli ultimi decenni l'areale di svernamento della Motacilla citreola si è espanso verso occidente includendo in modo rilevante il Medio Oriente e in misura minore l'Africa e la stessa Europa. Soprattutto nell'attivazione delle rotte più occidentali, un ruolo fondamentale è stato svolto dalla dispersione post-involo dei giovani che, come osservato anche in altri passeriformi asiatici (p. es. luì di Pallas Phylloscopus proregulus, luì forestiero Phylloscopus inornatus, zigolo golarossa Emberiza leucocephalos), in autunno si sono mossi in direzioni diverse rispetto a quella tipica della loro specie. Il Medio Oriente e il Corno d'Africa stanno progressivamente aumentando la loro rilevanza come areee aggiuntive per lo svernamento della specie nel suo complesso. Allo stesso modo, se in Europa l'espansione dell'areale riproduttivo verso ovest continuerà anche in futuro, l'Africa occidentale, raggiunta attraverso Gibilterra, potrebbe diventare una ulteriore area di svernamento rilevante. In analogia con quanto si sta osservando per la cutrettola Motacilla flava, anche la stessa Europa sta entrando a far parte dell'area di svernamento della specie. Infatti, oltre a constatare un aumento del numero di svernamenti nel sud del continente, si nota anche una progressione dei casi verso nord.

Parole chiave: Motacilla citreola, cutrettola testagialla orientale, espansione dell'areale riproduttivo, espansione dell'areale di svernamento, rotta migratoria, dispersione giovanile, migrazione inversa.

\section{INTRODUCTION}

Over the last century there have been many environmental changes in Europe both as a result of profound changes in land use caused by anthropogenic activity (intensification and mechanization of agricultural activities, widespread use of chemicals, water pollution, strong 
urbanization processes, abandonment of mountains, etc.) and as a consequence of climate change (Feranec et al., 2010; European Environment Agency, 2017; Hellwig et al., 2019). All these factors have influenced bird populations, sometimes in a negative way, but in some circumstances, also favouring the expansion of the breeding range towards the west in some Asian or Eastern European species (Isenmann, 1990; Newton, 2008; Cuervo \& Møller, 2013). Among the species that have shown this trend we can, for example, mention: great egret Casmerodius alba, pallid harrier Circus macrourus, red-flanked bluetail Tarsiger cyanurus, black-headed bunting Emberiza melanocephala, common rosefinch Carpodacus erythrinus, and citrine wagtail Motacilla citreola (Cramp, 1988; Isenmann, 1990; Ławicki, 2014; Mikkola, 2014; Dutch Montagu's Harrier Foundation, 2017; Henry, 2018; Anthes et al., 2019; Jubete Tazo \& Mougeot, 2019; Studecky, 2021). All listed species are migratory. Particularly, red-flanked bluetail, black-headed bunting, common rosefinch, and citrine wagtail are long-range migratory species that historically have their own wintering ranges concentrated in Southern Asia.

Berthold (2001) stated that, although migratory behaviour is mainly controlled by genetic factors, there is evidence for a high degree of flexibility and adaptability; thus, in the event of specific environmental changes, the genetic basis for rapid and diverse microevolutionary development affecting patterns of future bird migration is already present. Possible adaptations also include changes to migratory directions and the choice of new, closer winter quarters (Berthold, 1998; Morganti, 2015).

It is therefore legitimate to ask whether the long-range migratory species that have expanded their reproductive range to the west in Europe have also established new migratory routes and wintering ranges.

To evaluate these aspects, we have analysed the case of the citrine wagtail Motacilla citreola.

The citrine wagtail is a polytypic species. Three subspecies are recognized: M. c. citreola Pallas, 1776, M. c. werae (Buturlin, 1907), and M. c. calcarata Hodgson, 1836 (Clements et al., 2019; Tyler \& Kirwan, 2020). The werae subspecies is not accepted by all authors due to the similarity of many individuals with the citreola subspecies

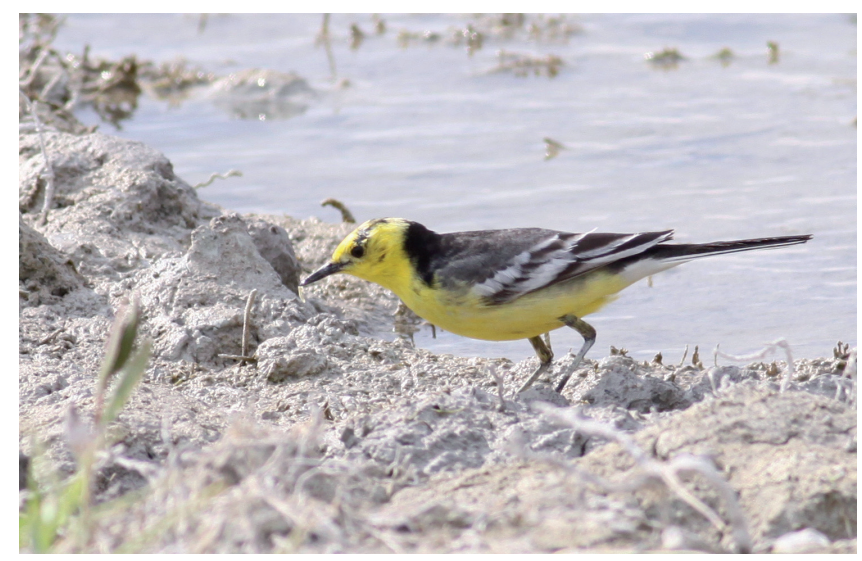

Fig. 1 - Motacilla citreola werae. Male, May, Turkey. / Maschio, maggio, Turchia. (Photo / Foto: Klaus Malling Olsen). and is therefore considered for this a simple form of the nominal subspecies (Alström et al., 2003; Gill \& Donsker, 2020). Compared to the Siberian breeding taxon citreola, werae is slightly smaller with a relatively shorter tail and longer legs (Barthel, 1990; Malling Olsen, 1990) (Figs. $1,2)$. Males are duller yellow, lacking a cold greenishyellow tinge typical to citreola (some werae males have a slightly browner undertone to the yellow head and underside). The upperparts are generally slightly duller with a less developed and clear-cut neck-bar (but may be as pronounced as in citreola), flanks are normally concolourous with the belly, or with grey confined to upper flanks, even in females. All adult citreola studied (e.g., in Siberia - our own studies June 1989) showed contrasting grey flanks (Fig. 3), which tends to enforce the white wing-bars (this is even true in $1^{\text {st }}$ year birds). The breeding ranges of the two subspecies are furthermore well separated (although a contact zone probably exists in Central Asia), with $c i$ treola inhabiting North Russia to Central Siberia, Mongolia, and NW Manchuria and werae in Eastern Europe

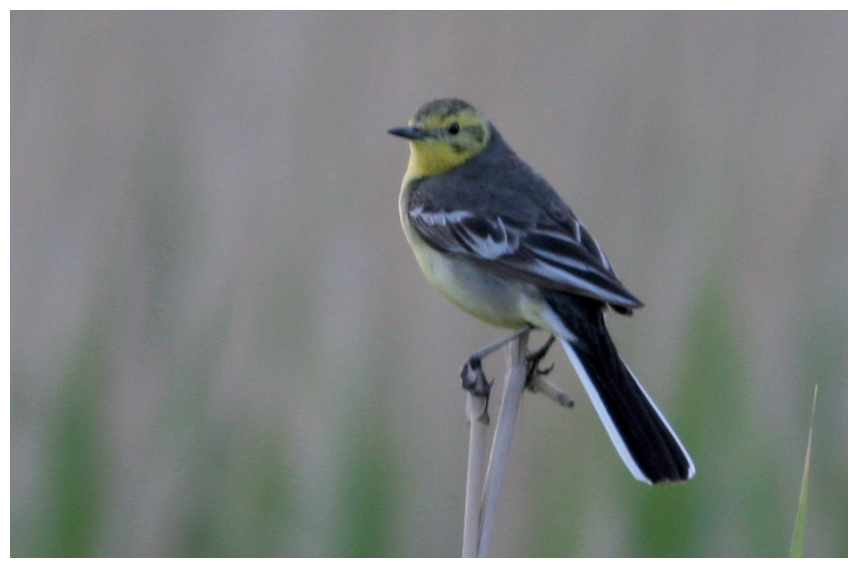

Fig. 2 - Motacilla citreola werae. Female, May, Turkey. / Femmina, maggio, Turchia. (Photo / Foto: Klaus Malling Olsen).

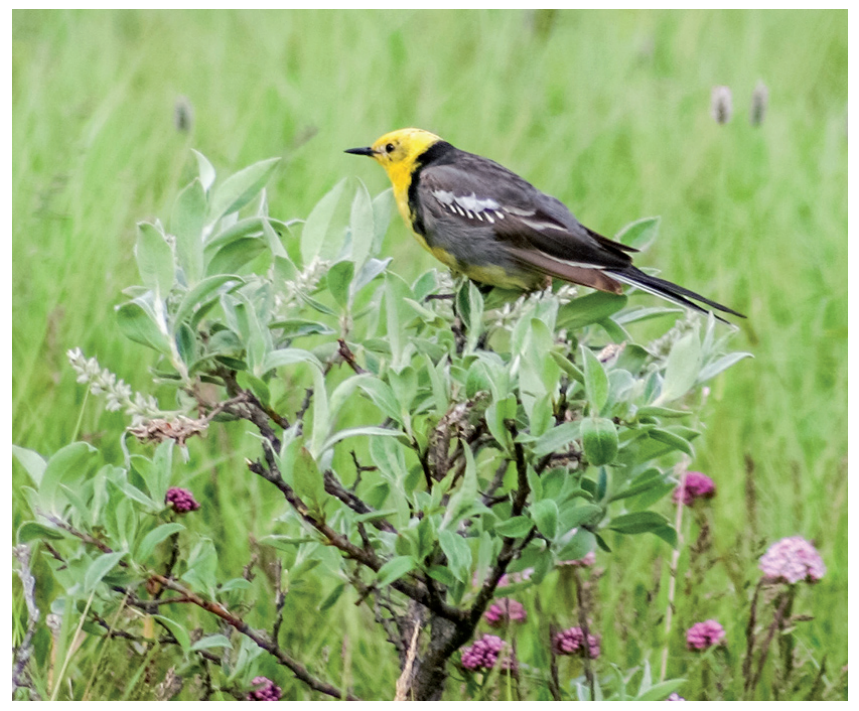

Fig. 3 - Motacilla citreola citreola. Male, July, Yamalsky District, Yamalo-Nenets Autonomous Okrug, Russia. / Maschio, luglio, Distreto di Jamalskij, circondario autonomo Jamalo-Nenec, Russia. (Photo / Foto: Alexander Yakovlev). 
to Russian Altai, Kasakhstan, and NW China. The males of subspecies calcarata have an entire head and underbody in strong yellow, a mantle and back completely black, and a rump black or dark grey or a mixture (Shirihai \& Svensson, 2018) (Fig. 4). The breeding range of calcarata include South Turkmenistan, Kopet Dag, Afghanistan, Tien Shan, Tibet, and Himalaya. The three subspecies are roughly distributed as shown in Fig. 5.

As early as 1890 s, the western limit of the breeding range of the citrine wagtail in Europe ran through the territories of Ryazan, Tambov, Penza and Gorky regions, and in the 1930s the western limit was still 300 to $400 \mathrm{~km}$ east of Moscow (Sushkin, 1892; Naumann, 1897; Hartert, 1922; Dement'ev \& Gladkov, 1954); only by the beginning of the 1950s did the species penetrate into the Moscow Region, gradually extending its range westwards (Matveyenko, 1977; Wilson, 1979), and set-

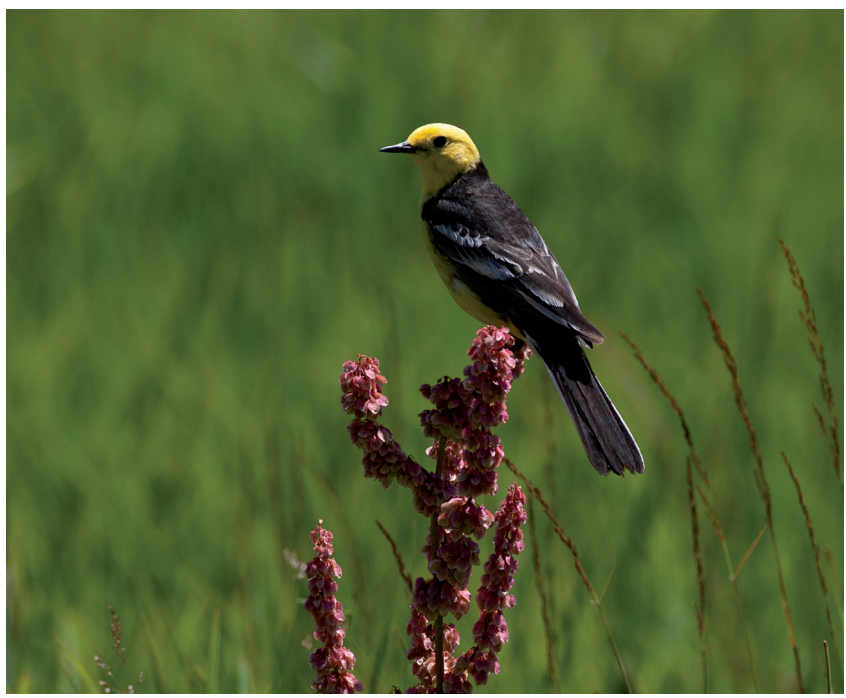

Fig. 4 - Motacilla citreola calcarata. Male, May, Kyrgyzstan. / Maschio, maggio, Kirghizistan (Photo / Foto: Tom Lindroos).

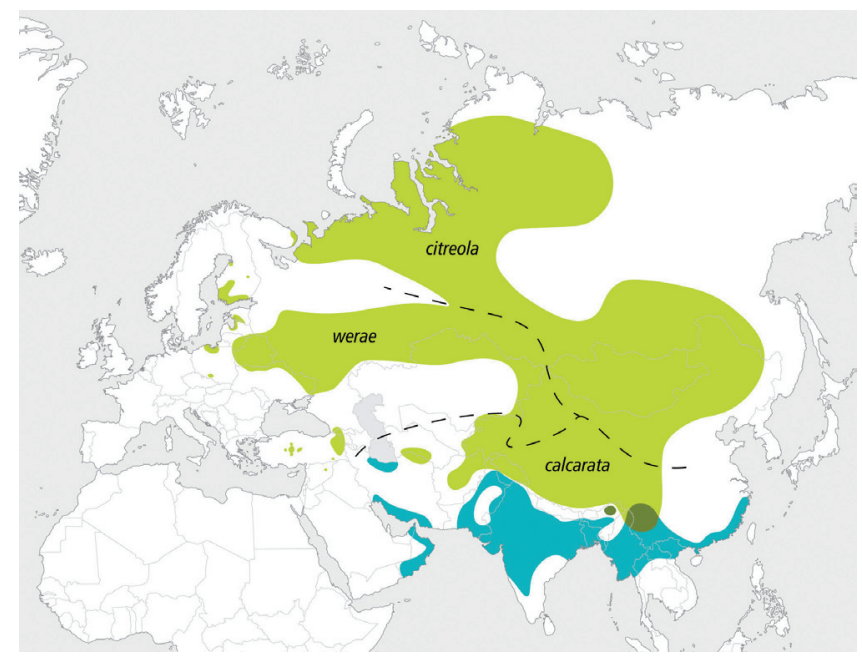

Fig . 5 - Distribution map of Citrine Wagtail subspecies (original map from Wielstra et al., 2019, redrawn by Sam Gobin and used with author's permission). / Mappa di distribuzione delle sottospecie della cutrettola testagialla orientale (mappa originale da Wielstra et al., 2019, ridisegnata da Sam Gobin e usata con l'autorizzazione dell'Autore). tling permanently into new territories (Fig. 6): Ukraine in 1976 (Matveyenko, 1977), Belarus in 1982, Lithuania in 1987 (Baumanis et al., 1997), Estonia in 1991 (Davies \& Sharrock, 2000), Latvia in 1993, and Poland in 1994 (Meissner \& Skakuj, 1997; Ściborska, 2004). Occasional nesting, often in mixed pairs with $M$. flava, has also occurred in other locations: in England in 1976 (Cox \& Inskipp, 1978), in Sweden from 1977 (Erdqvist, 1979), in Norway in 1997, 2001, 2008 and 2009 (Olsen et al. 2010), in Switzerland in 1997 and 2012 (Glutz von Blotzheim, 1997; Knaus, 2018), in Slovakia in 1997 and 2006 (Dobrota \& Topercer, 1998; Mošanský \& Karaska, 2002; Wilk et al., 2009), in the Czech Republic in 2003 (Sándor et al., 2007), in Romania in 2006 (Sándor et al., 2007), in France in 2010 (Laur-Fournié \& Paris, 2011), in Netherland in 2011 (Draaijer \& Slaterus, 2012), in Denmark in 2015 (Netfugl.dk, 2020), and in Serbia in 2016 (Medenica \& Mirić, 2015/2016). In Germany, a couple first nested in 1996 and isolated cases have repeated in subsequent years (Hampe et al., 1996; DSK, 2008; Wahl et al., 2011; Sud-

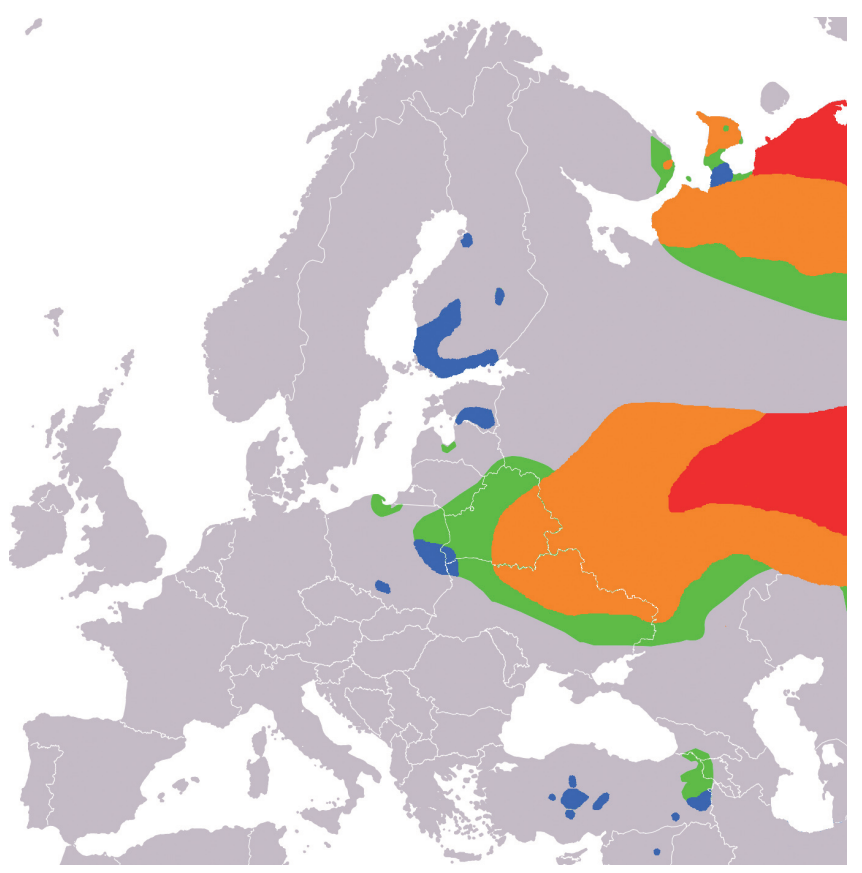

Fig. 6 - Evolution of the western breeding range of the citrine wagtail Motacilla citreola between 1890 and 2019. Red: breeding range between 1890 and 1950; orange: breeding range expansion between 1951 and 1985; green: breeding range expansion between 1986 and 2000; blue: breeding range expansion between 2001 and 2019 (redrawn from: Alexander Kürthy - Range map from BirdLife International 2016. Motacilla citreola. The IUCN Red List of Threatened Species 2016: e.T22718379A88052549). / Evoluzione dell'areale riproduttivo occidentale della cutrettola testagialla orientale Motacilla citreola tra il 1890 e il 2019. Rosso: areale riproduttivo tra il 1890 e il 1950; arancio: espansione dell'areale riproduttivo tra il 1951 e il 1985; verde: espansione dell'areale riproduttivo tra il 1986 e il 2000; blu: espansione dell'areale riproduttivo tra il 2001 e il 2019 (ridisegnato da: Alexander Kürthy Range map from BirdLife International 2016. Motacilla citreola. The IUCN Red List of Threatened Species 2016: e.T22718379A88052549). (Sources / Fonti: Sushkin, 1892; Naumann, 1897; Hartert, 1922; Dement'ev \& Gladkov, 1954; Matveyenko, 1977; Cramp, 1988; Barthel, 1990; Meissner \& Skakuj, 1997; Snow \& Perrins, 1998; Alström et al., 2003; Nikiforov, 2008; Kruszewicz, 2013; BirdLife International, 2020a; Tyler \& Kirwan, 2020; Red'kin \& Kalyakin, 2020). 
feldt et al., 2012; 2013; DAK, 2014; Krüger et al., 2014; Gerlach et al., 2019). A possible mixed couple was also observed in northern Italy in 1989 (Carlotto et al., 1994).

In addition to Western Europe, starting from 1981 the breeding range of the species has also expanded in Turkey and then, gradually, also in Armenia and Georgia (Kasparek, 1992; Ananian \& Busuttil, 2002; Kirwan et al., 2008; Abuladze \& Edisherashvili, 2018).

As already mentioned, the evolution of the breeding range of the species in Europe has been carefully documented over time by many authors, moreover an updated situation has been provided by the European Breeding Bird Atlas 2 (Red'kin \& Kalyakin, 2020).

This research aims instead to provide an overall view of the evolution that both migratory movements and the wintering area of the species in Europe, the Middle East, and Africa have undergone over time.

\section{MATERIALS AND METHODS}

The study takes into consideration the period from 1848 (first report of Motacilla citreola in Europe) to 2019 in the following geographical areas:

- Europe (with exception of the countries where the species is now a regular breeder: Russia, Ukraine, Belarus, Lithuania, Latvia, Estonia, Finland, and Poland)

- Middle East (Bahrain, Cyprus, Egypt, Iran, Iraq, Israel, Jordan, Kuwait, Lebanon, Oman, Palestine, Qatar, Saudi Arabia, Syria, Turkey, United Arab Emirate, and Yemen)

- Transcaucasia (Armenia, Azerbaijan, and Georgia)

- Africa (the whole continent, including Madeira, Canary Islands, and Cape Verde Islands).

The study is based on data and information obtained from some national ornithological rarities committees, 535 bibliographic sources, 145 travel reports, 18 databases, and 20 websites.

A total of 10,513 reports (22,885 birds) were collected as follows: 3,627 for Europe (3,800 birds), 6,197 for the Middle East (16,074 birds), 605 for Transcaucasia (2,905 birds), and 73 for Africa ( 76 birds). All data relate to autumn (from $1^{\text {st }}$ August to $30^{\text {th }}$ November), winter (from $1^{\text {st }}$ December to the end of February), and spring (from $1^{\text {st }}$ March to $31^{\text {st }}$ May). For the Middle East and Transcaucasia, the spring period was considered to have ended on $16^{\text {th }}$ May.

Although it was our intention to collect all the observations for the area and period of study, it is certain that a portion is missing from our dataset. For Europe and Africa, we estimate that the level of completeness is above $90 \%$, while for the Middle East and Transcaucasia it is lower. A term of comparison can be constituted by Oman: our sample data, collected by consulting the main online ornithological platforms and journals in the sector, consists of 825 records for a total of 2,458 birds, while, thanks to the courtesy of Jens Eriksen, we know that the reports are at least 3,600. Assuming that this proportion is also respective of other countries in the Middle East and Transcaucasia, the level of coverage of our sample for this area is at least $22.9 \%$, therefore sufficiently large to be able to describe the current trends.
Starting from the 1960s and for all subsequent decades, the data were graphically transposed on maps using red circles of proportional size to the number of individuals reported at the decade level in regions or macro-regions of the different countries. The black circles indicate that more than 100 individuals have been counted in the decade. Although we are aware that there are differences in the size of the areas represented by the individual circles, we believe that the phenomena investigated are in any case well perceptible.

\section{RESULTS}

In consideration of its very scarce appearances in Western Europe, until the mid-twentieth century the citrine wagtail was considered a purely oriental species (Dresser, 1871-1881; Naumann, 1897; Arrigoni degli Oddi, 1904; Hartert, 1922). Until September 1954 only very rare observations were known, all concentrated in the nineteenth century, relating to the Heligoland archipelago (an English territory from 1814 to 1890 , subsequently assigned to Germany), Transylvania (Romania), and Veneto (Italy). In the Heligoland Islands, the first capture, on $26^{\text {th }}$ September 1848 , was followed by four others $\left(15^{\text {th }}\right.$ November $1861,25^{\text {th }}$ September $1870,28^{\text {th }}$ December 1886 , and one undated); in all cases they were single individuals in the first calendar year (Gätke, 1895; Glutz von Blotzheim \& Bauer, 1985). In Transylvania, an individual was captured near Cluj-Napoca, probably after 1870 (Danford \& Harvie-Brown, 1875), while in Veneto, on $29^{\text {th }}$ April 1900 at Scanno dei Tre Porti (sea of Venice), three adult individuals were captured (Arrigoni degli Oddi, 1904). At the beginning of the twentieth century, Nicoll (1919) and Wardlaw-Ramsay (1923) indicated the species of rare occurrence even in Egypt (all of those known were firstwinter individuals), and in Israel an individual was observed in September 1917 (Shirihai, 1996).

In the 1940s, citrine wagtail was reported in Iran, Iraq, and Israel. Two specimens (males) found in Iran are preserved in skin at the Field Museum of Natural History in Chicago and were collected in the Lorestan Province respectively on $27^{\text {th }}$ March 1941 in Dorus and on $20^{\text {th }}$ July 1941 in Borūjerd (Grant \& Marks, 2020). In Iraq, an individual was observed in the Mosul area (Nineveh Governorate) on the Khosar stream on 23 $3^{\text {rd }}$ March 1945 (Moore \& Boswell, 1956). In Israel, an individual was observed on $27^{\text {th }}$ May 1944 (Shirihai, 1996).

The species reappeared in Europe only in 1954 when two different first-winter individuals were captured at Fair Isle, Shetland on $20^{\text {th }}$ September and $1^{\text {st }}$ October 1954 (Sharrock \& Sharrock, 1976; Williamson, 1982). In 1957 the citrine wagtail was observed for the first time in the Caucasus (Julfa District of the Nakhchivan Autonomous Republic in Azerbaijan): in the days between $11^{\text {th }}$ and $14^{\text {th }}$ April, at least 26 individuals were observed in mixed groups with Motacilla flava and Motacilla alba (Ochapovsky, 1965). One male was captured and attributed to the subspecies werae (Ochapovsky, 1965).

During the 1960s, the species reappeared five more times in the Shetland Islands and in Great Britain, again in the autumn between $4^{\text {th }}$ September and $17^{\text {th }}$ October $(\mathrm{Py}-$ 
man \& the Rarity Records Committee, 1961; Swaine \& the Rarities Committee, 1962; Harber et al., 1963; Harber \& the Rarities Committee, 1965; Smith \& the Rarities Committee, 1968; 1969; 1970) (Fig. 7). After those of 1900, a new spring appearance occurred in Western Europe (Fig. 8): a male was observed in the Rhine delta (Vorarlberg, Austria) on 12 ${ }^{\text {th }}$ April 1964 (Jacoby, 1964). During the spring migration, the species was also reported in the Middle East (Fig. 8): an individual in Oman on 29 $9^{\text {th }}$ March 1961 (Jens Eriksen, pers. com.), an individual in Isparta (western Turkey) on 12 $2^{\text {th }}$ May 1964 (Vauk, 1964), another one in Zarqa (Jordan) on $2^{\text {nd }}$ May 1966 (Wallace, 1982), a flock was observed in Iran near the Tis-rud estuary (Gilan Province) in mid-April 1966 (Nielsen, 1969), and an individual

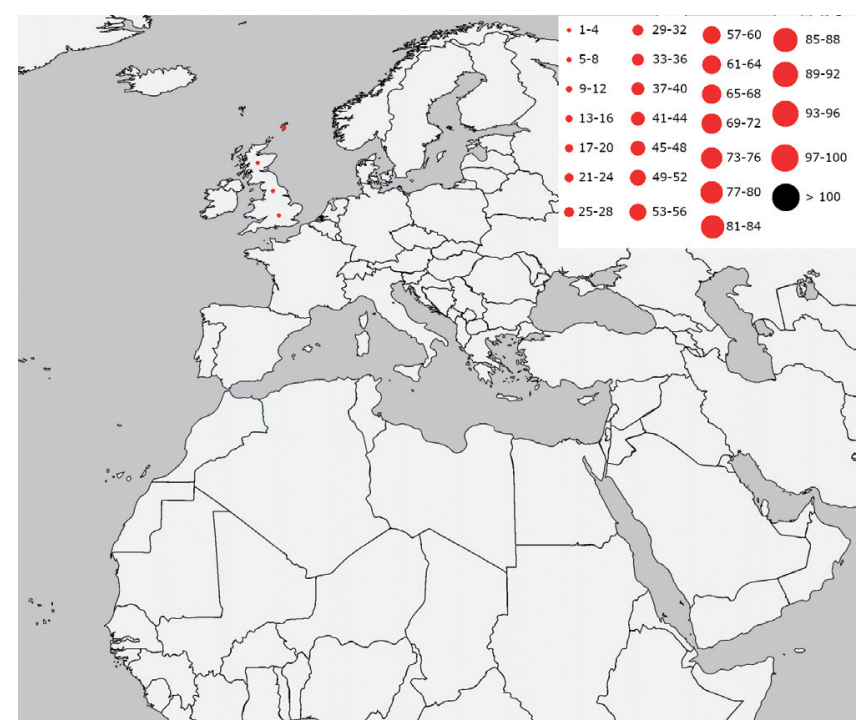

Fig. 7 - Distribution map of citrine wagtail in autumn in the 1960s. / Mappa di distribuzione autunnale della cutrettola testagialla orientale negli anni 1960.

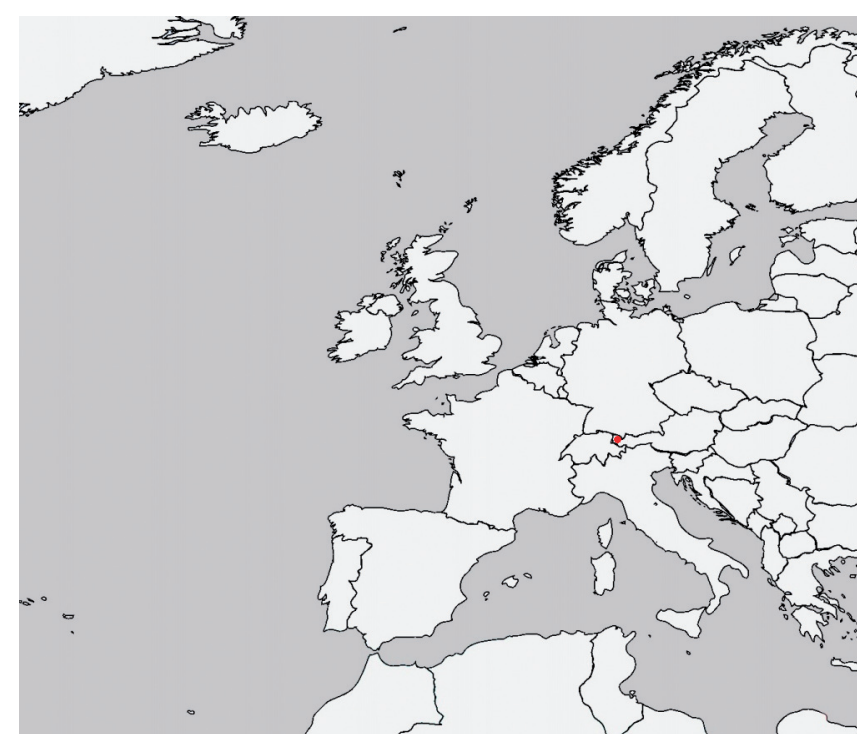

Fig. 8 - Distribution map of citrine wagtail in the spring in the 1960 s. / Mappa di distribuzione primaverile della cutrettola testagialla orientale negli anni 1960.
In the 1970s, the autumn presence of the species in northern Europe was further confirmed, both in the British Isles and in Scandinavia (Map 5). But the species went even further west, reaching Iceland for the first time on $31^{\text {st }}$ October 1973 (Pétursson \& Dráinsson, 1999). In the British Isles, as in the previous decade, all 13 observations concerned first-winter individuals while adult individuals were also reported in Scandinavia. In the Middle East, citrine wagtail, although very scarce, was reported in autumn in the Arabian Peninsula, with presences concerned both the Red Sea coast and the Persian Gulf (Fig. 9). Wintering was ascertained mainly in the area around the Persian Gulf: Oman, United Arab Emirates, Saudi Arabia (Damman marsh), Iraq (marshes at Haur Aluwez) and Iran (Khuzestan) (Fig. 10). In the latter area, accord-

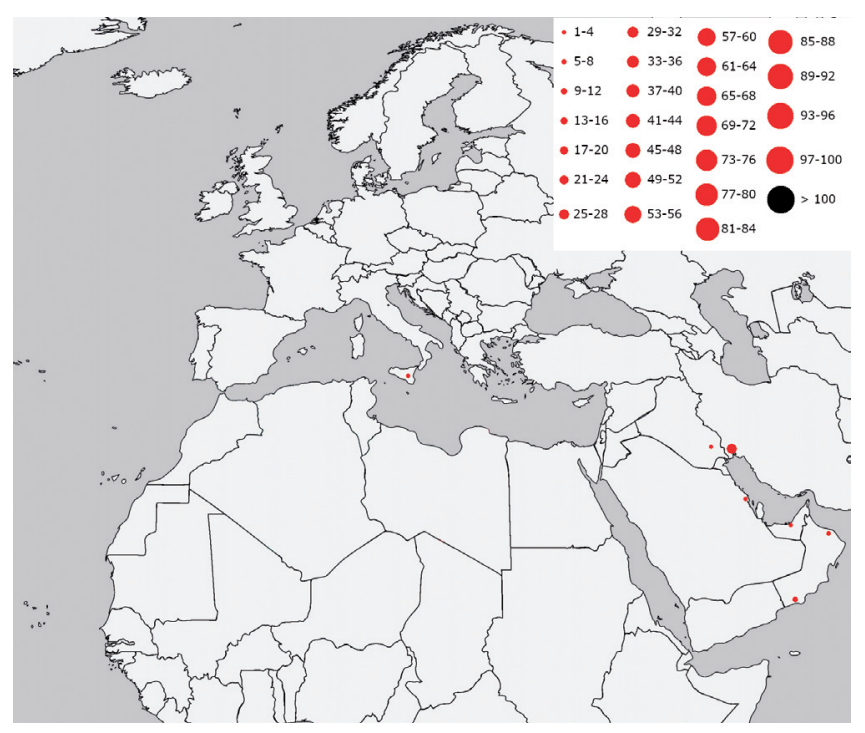

Fig. 9 - Distribution map of citrine wagtail in autumn in the 1970s. / Mappa di distribuzione autunnale della cutrettola testagialla orientale negli anni 1970.

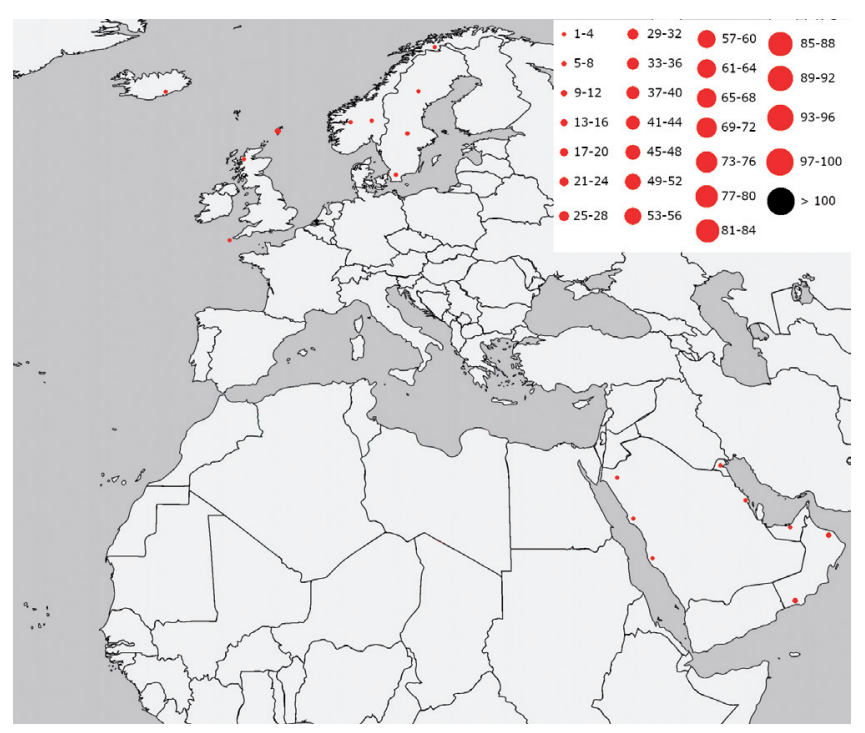

Fig. 10 - Distribution map of citrine wagtail in the winter in the 1970s. / Mappa di distribuzione invernale della cutrettola testagialla orientale negli anni 1970. 
ing to Scott \& Carp (1982), the species was quite common in winter. In the same decennium, for the first time, the species wintered also in Europe: a first-winter individual was observed in Sicily (Italy) on $30^{\text {th }}$ December 1974 (Brichetti \& Fracasso, 2007). In spring (April-first decade of May) the species was confirmed in the Middle East: in the Arabian Peninsula, Israel, Syria, and Turkey (Central Anatolia) (Fig. 11). In Europe, there were only four spring reports (Fig. 11): one individual was observed in Wesertal (Hesse, Germany) on $25^{\text {th }}$ May 1972 (Schelper, 1973), one in Liguria (Italy) on $1^{\text {st }}$ May 1976 (Brichetti \& Fracasso, 2007), and probably in the spring of the following year, one in Slovakia (Kanuscak, 1977); finally one was observed on $29^{\text {th }}$ April 1978 in Eastern Macedonia and Thrace (Greece) in the Nestos delta (Inskipp, 1979).

In the 1980s, the regular autumn appearance of the citrine wagtail in northern Europe was reconfirmed with presences in Sweden, Norway, Denmark, Heligoland, Netherlands, the British Isles and, once again, Iceland (Fig. 12). As in the 1970s, both first-year and adult individuals were observed in Scandinavia in autumn, while in the far western countries only first-winter individuals arrived. The appearance of the species in Southern Europe is also completely new with a special mention for the first autumn report in Spain in the Barcelona area on $12^{\text {th }}$ September 1987 (Grant, 1988) (Fig. 12). Also in this case, the observed individual was a first-winter, while the two individuals observed respectively on $17^{\text {th }}$ September 1987 in Austria (Vorarlberg) (Ranner et al., 1995) and on $15^{\text {th }}$ August 1989 in Italy (Veneto) (Brichetti \& Fracasso, 2007) were both males. In the Middle East, a more abundant flow was noted along the Arabian coast of the Persian Gulf and, due to the first OSME expedition to Yemen, the presence of the species was also ascertained in this country (Brooks et al., 1987). The same authors also documented wintering in Yemen by specifying that they also observed a male in breeding plumage showing characteristics of the subspecies citreola at Ta'izz

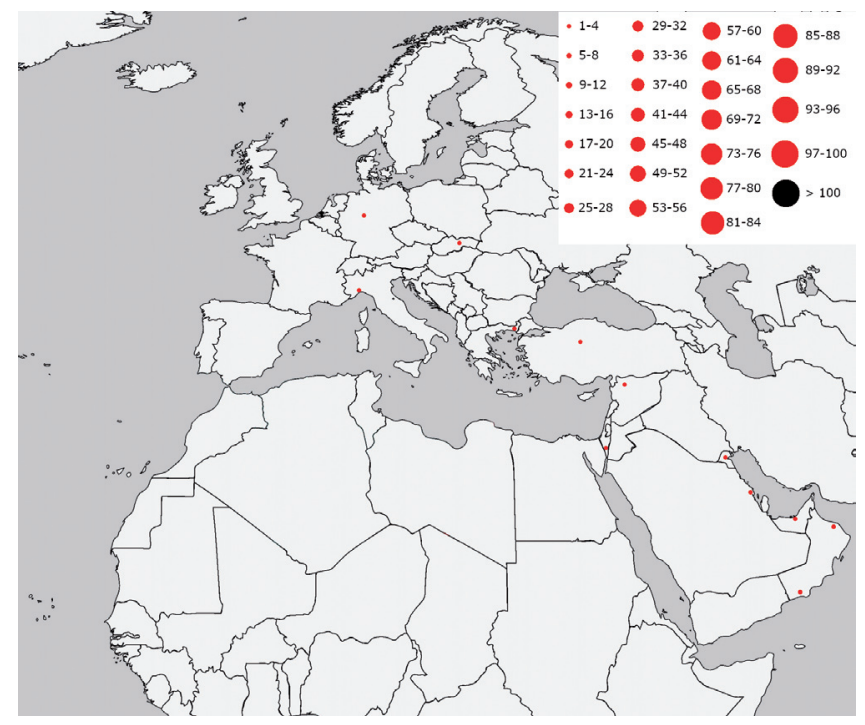

Fig. 11 - Distribution map of citrine wagtail in the spring in the 1970s. / Mappa di distribuzione primaverile della cutrettola testagialla orientale negli anni 1970. reservoir on $14^{\text {th }}$ February 1986 (Brooks et al., 1987). Even in the 1980s, the species overwintered in various locations on the Arabian Peninsula and proved to be relatively common in Khuzestan Province (Iran) (Fig. 13). An exception was the presence of a male in Norway in Larvik (Vestfold and Telemark), on $18^{\text {th }}$ December 1983 (Karl Petter Gade in artsobservasjoner.no, 2020), as well as the first report of an individual in Morocco in Merja Zerga (Rabat-Salé-Kénitra Region) on $4^{\text {th }}$ January 1989 (Bergier et al., 2000). In spring (Fig. 14), in the Middle East the migratory movement of birds towards the north was concentrated mainly in the area north of the Red Sea, then continuing through Cyprus, the western part of Turkey, and the neighboring Greek islands, until it entered the European continent through Greece and Bulgaria. In

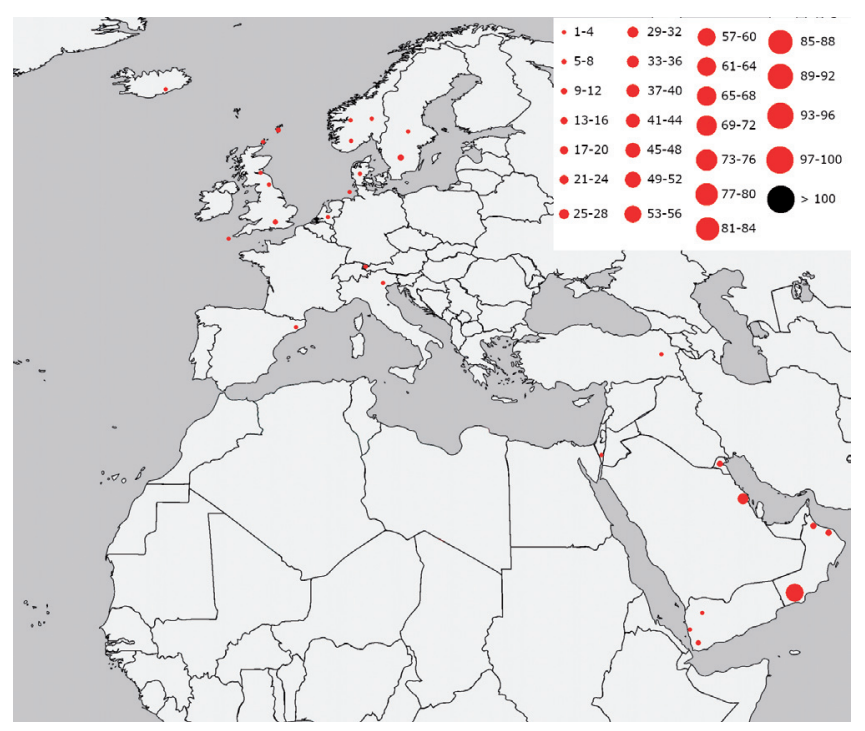

Fig. 12 - Distribution map of citrine wagtail in autumn in the 1980s. / Mappa di distribuzione autunnale della cutrettola testagialla orientale negli anni 1980.

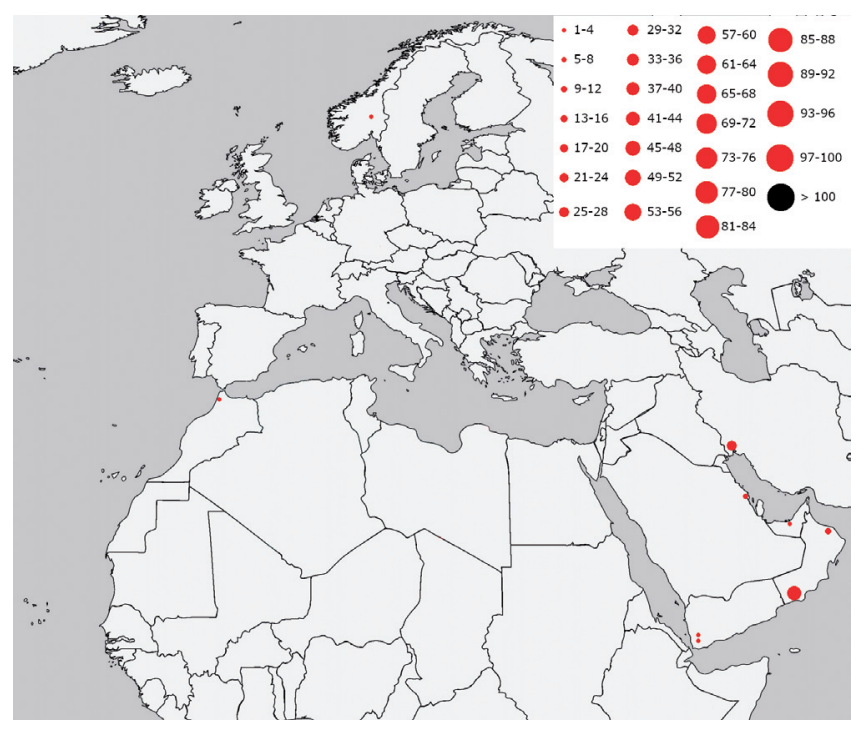

Fig. 13 - Distribution map of citrine wagtail in the winter in the 1980s. / Mappa di distribuzione invernale della cutrettola testagialla orientale negli anni 1980. 


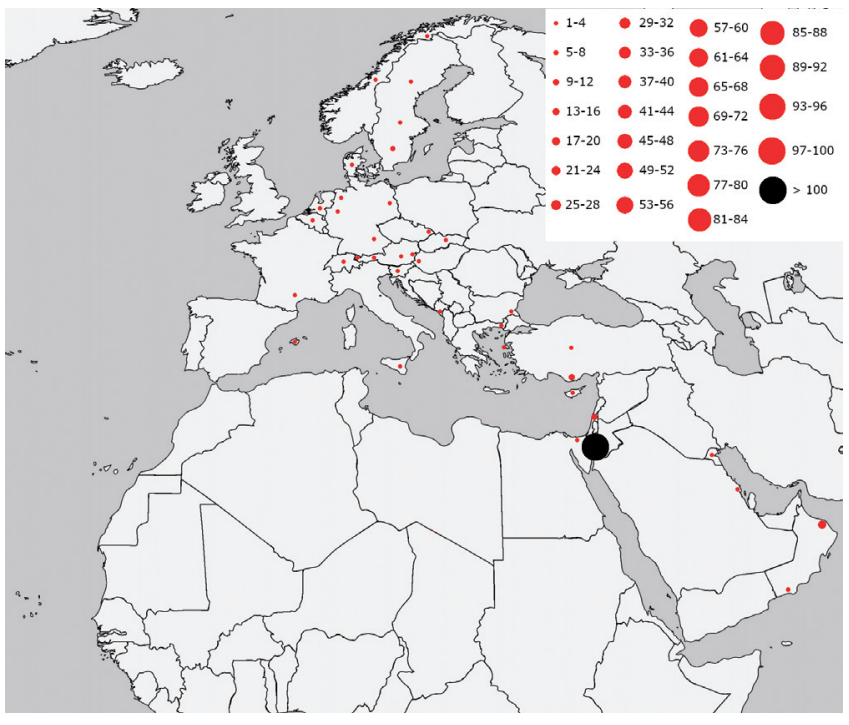

Fig. 14 - Distribution map of citrine wagtail in the spring in the 1980s. / Mappa di distribuzione primaverile della cutrettola testagialla orientale negli anni 1980.

eastern and central Europe, as well as in Scandinavia, there were widespread presences to which a contribution from individuals from more eastern routes cannot be excluded. Similarly to what was observed in autumn, the species made its first spring appearance in Spain (Mallorca, Balearic Islands, on $14^{\text {th }}$ April 1987) (Grant, 1988), and also in southern France (Occitania in April 1987 and April 1989) (P. Fiquet, M. Jourdan, A. Rouge et al. in CHN, 2020).

In the 1990s in autumn, movements in Europe towards the west became even more intense and evident (Fig. 15). While both adults and first year individuals were observed in Scandinavia and Central Europe (Denmark, Germany, Netherlands, Belgium), further west (British Isles, Iceland, France, Spain, Portugal) the migratory flow was

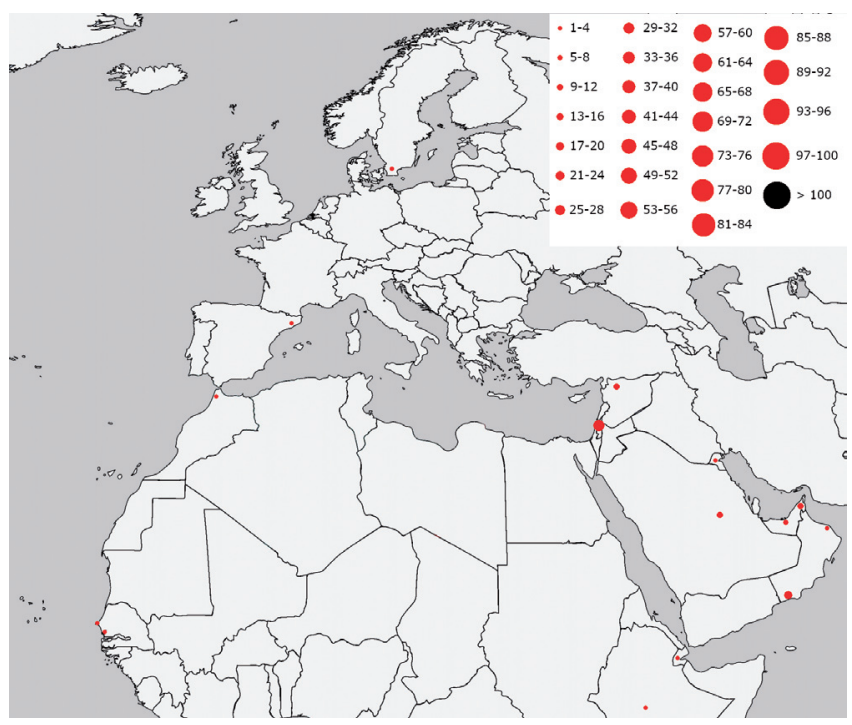

Fig. 15 - Distribution map of citrine wagtail in autumn in the 1990s. / Mappa di distribuzione autunnale della cutrettola testagialla orientale negli anni 1990. almost completely constituted by individuals born in the year. There were very few presences in the Balkan area, in Greece, and in Cyprus. In the Middle East, the migratory flows already highlighted in the previous decade were confirmed, with a particular presence in the southern part of Oman (Dhofar Governorate). New reports were instead received from the Egyptian coast of the Red Sea (a female in Hurghada on $21^{\text {st }}$ September 1992) (Schollaert, 1998) and from the course of the Nile (Abu Simbel, September 1996) (Schollaert, 1998), as well as those relating to the central part of Ethiopia (an adult female in Hosaina on $11^{\text {th }}$ November 1994 and an individual in Awash West on $25^{\text {th }}$ October 1996) (Schollaert, 1998). In Israel, 90\% of the individuals observed in autumn were in their first year (Shirihai, 1996). The logical consequence of the autumn observations in Africa was the overwintering of the citrine wagtail in Ethiopia (Oromia Region) (Schollaert, 1998; Farnsworth et al., 2000), and Djibuti (Keith et al., 1992) (Fig. 16). The species confirmed its winter presence in the Arabian Peninsula and, further north, in Israel (Haifa District) (GBIF.org, 2020) and Syria (Aleppo Governorate) (Wester, 1998). On the west coast of Africa, the wintering of Motacilla citreola in Morocco (an individual in the Lower Loukkos Marshes on $3^{\text {rd }}-5^{\text {th }}$ January 1995) was again confirmed (Bergier et al., 2000) and, for the first time, single individuals were also observed in Senegal (Saloum Delta National Park on 27 $7^{\text {th }}$ January 1997 and near Dakar on $16^{\text {th }}-29^{\text {th }}$ January 1999) (Schepers et al., 1998; Gruwier et al., 2001). One individual was observed in Scania (Sweden) in January-February 1993 (Max Jensen, Thomas Kraft in artportalen.se, 2020). Also in spring, the presence of citrine wagtails was detected migrating in the Horn of Africa and Egypt, as well as in the Arabian Peninsula (Fig. 17). Quite unexpectedly, on $27^{\text {th }}$ April 1998 an individual was observed at Gamtoos River mouth, Eastern Cape Province, South Africa, where it remained until $6^{\text {th }}$ May (Branch, 1998), and on $16^{\text {th }}$ April 1999 an adult female was observed in the island

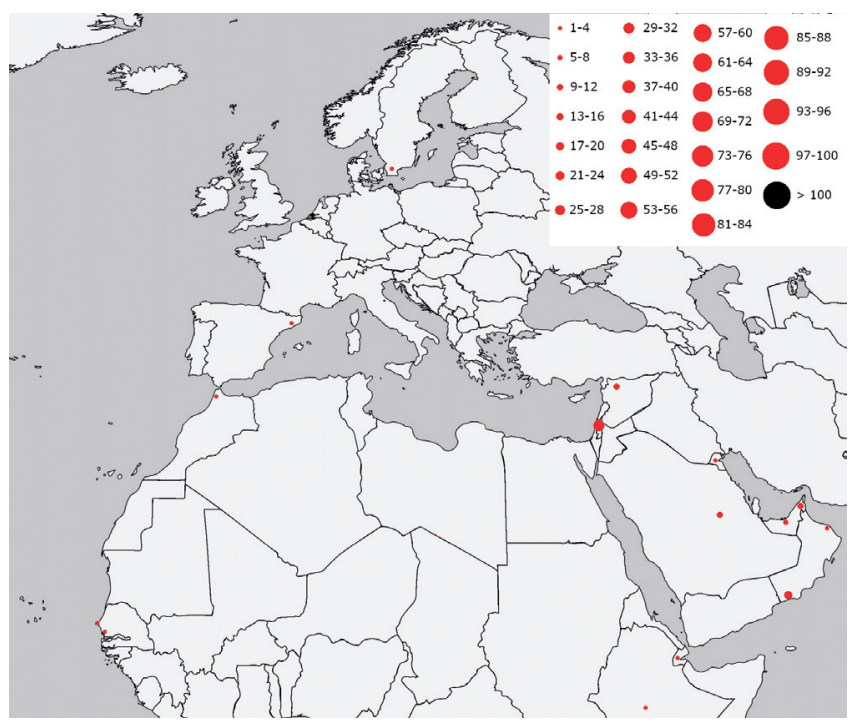

Fig. 16 - Distribution map of citrine wagtail in the winter in the 1990s. / Mappa di distribuzione invernale della cutrettola testagialla orientale negli anni 1990. 


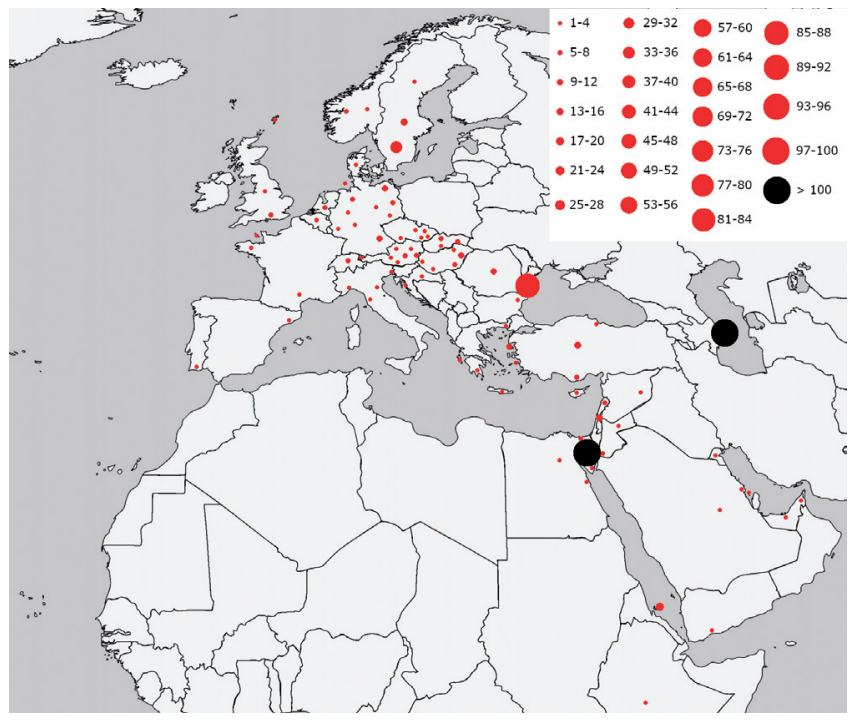

Fig. 17 - Distribution map of citrine wagtail in the spring in the 1990s. / Mappa di distribuzione primaverile della cutrettola testagialla orientale negli anni 1990.

of Frégate (Seichelles) (Skerrett, 2001). Further north, the species was observed with particular regularity in Israel and, more widely, in the countries up to Turkey. More to the east, the migratory flow (about 500 individuals mixed with western yellow wagtails) observed on $4^{\text {th }}$ April 1998 by a vessel operating in the Caspian See out of Baku (Azerbaijan) was decidedly important (Hingston et al., 2005). In Europe, a widespread northward flow through Greece and its islands was confirmed, while the intensity of the passage along the west coast of the Black Sea in April 1996 was absolutely new, as reported by Schmitz (1998) for Romania. In central-eastern Europe and Scandinavia, there were generally few, but widespread, presences. Starting from 1990, after the many autumn presences, there were also spring observations in the British Isles for the first time. As expected in consideration of the winter presences along the northwestern coast of Africa and in Spain, in the southern part of the Iberian Peninsula, along the Mediterranean coast, and in southern France, a weak migratory flow was observed. The presences that were detected in the northern part of Italy could be attributable both to this flow from the west and to entrances from the east.

In the 2000s in autumn, movements in Europe towards the west intensified (Fig. 18). While in Scandinavia and Central Europe, both adults and first year individuals were observed, further west (British Isles, Faroe Islands, Iceland, northern France) the migratory flow was still largely dominated by individuals born in the year, however with an evident increased attendance of adults. As in the previous decade, the presences in the Balkans and Eastern Europe were modest. In Italy, four individuals were reported in the northeast, and for the first time an individual (first-year) was observed in Linosa (Pelagie Islands) on $25^{\text {th }}$ October 2008 (Ottavio Janni in Ornitho. it, 2020). The presences in southern France (ProvenceAlpes-Côte d'Azur and Occitanie), along the Mediterranean coast of Spain and in the Balearic Islands now clearly outlined a regular migratory route towards northwestern Africa which had, as a logical consequence, the observation of an individual (first-year) in Tenerife (Canary Islands) on $11^{\text {th }}$ October 2000 (de Juana \& el Comité de Rarezas de la Sociedad Española de Ornitología, 2002). For the first time the species also reached the Azores: an individual was observed in Corvo Island on $14^{\text {th }}$ and $15^{\text {th }}$ September 2009 (Matias et al., 2012). In the Middle East, the presence increased further, with an evident contribution of birds that arrived through the Caucasus. In winter (Fig. 19), the species once again reached the Horn of Africa with individuals wintering in the Socotra Archipelago, Djibouti, and Eritrea. Furthermore, exceptionally, the species was also reported south of the Equator: a male was observed in Ngorongoro Cra-

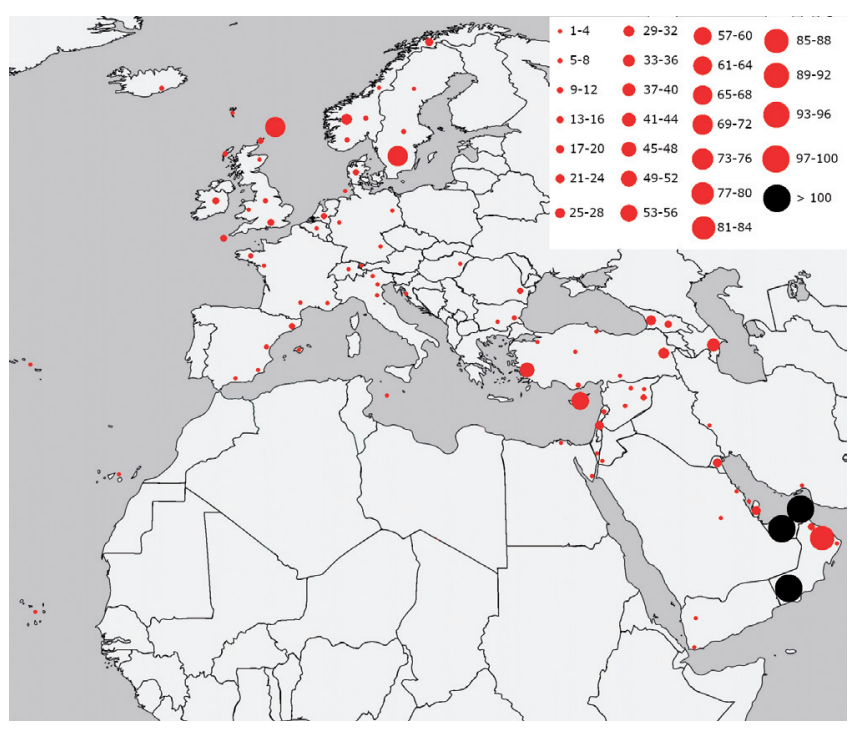

Fig. 18 - Distribution map of citrine wagtail in autumn in the 2000 s. / Mappa di distribuzione autunnale della cutrettola testagialla orientale negli anni 2000.

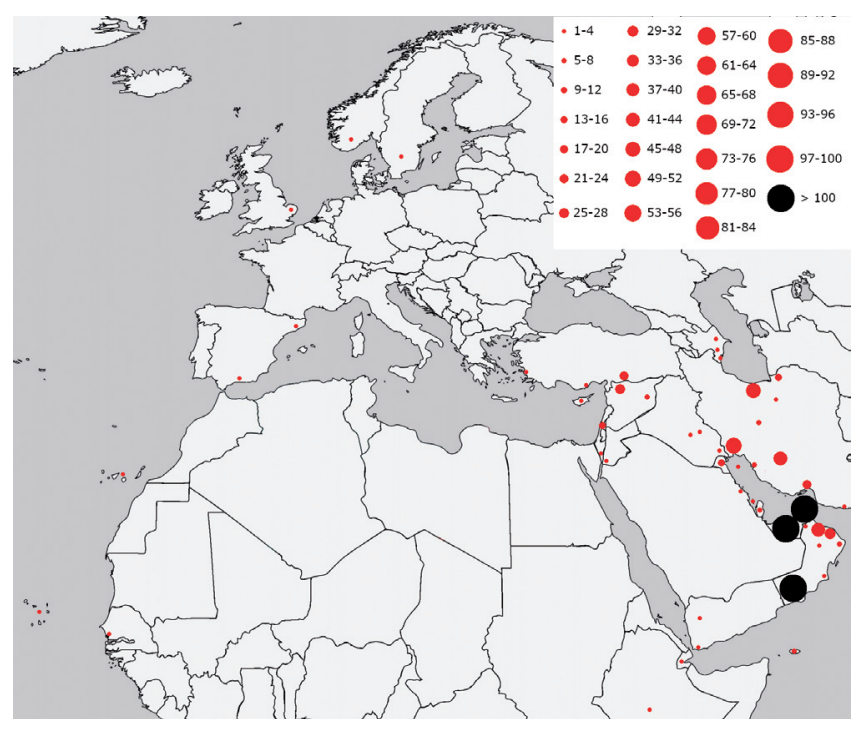

Fig. 19 - Distribution map of citrine wagtail in the winter in the 2000s. / Mappa di distribuzione invernale della cutrettola testagialla orientale negli anni 2000. 
ter (Tanzania) on $20^{\text {th }}$ February 2006 (Hans Diepstraten in Observation.org, 2020; record not yet reviewed by the East African Rarities Committee, Neil Baker, pers. com.). The citrine wagtail further consolidated its presence in the Middle East, becoming relatively common in the United Arab Emirates and Oman, and wintering widely throughout the area with particularly significant presences in Iran. The northward expansion of the wintering range also appeared evident in consideration of the first presences (not only of individuals, but also of groups) in Azerbaijan and Turkey. For the first time, an individual was observed during winter in Cyprus on $21^{\text {st }}$ December 2002 (Colin Ricardson, pers. com.). In Northern Europe, occasional appearances were recorded in Sweden, Norway, and England. In the west, wintering along the Mediterranean side of Spain and along the Atlantic coast of Africa was confirmed with presences in the Canaries (first-winter, Lanzarote, from $20^{\text {th }}$ November 2005 to $18^{\text {th }}$ January 2006) (Dies et al., 2007), Cape Verde (Sal, an individual $7^{\text {th }}-10^{\text {th }}$ January 2008 and a female on $21^{\text {st }}$ February 2008) (Hazevoet, 2010), and Senegal (Saloum Delta National Park on $21^{\text {th }}$ February 2007) (Marc Detollenaere in Observation.org, 2020). In January-February 2007, a citrine wagtail was reported from a wetland near Birni N'Konn (Tahous Region), in the southwestern part of Niger, but this report has not been approved (Joost Brouwer, pers. com.). Some bibliographic sources indicated the observation of the species also in Cameroon, but it was probably just an error (Robert Dowsett, pers. com.). During the spring migration (Fig. 20), the species was observed both in Egypt and in the Middle East. The areas with the greatest presence were the south-eastern part of the Arabian Peninsula, the south-eastern edge of the Caspian Sea in Iranian territory (Ashuradeh, Golestān Province) (Balmer \& Betton, 2008), the Caucasian area, Western Turkey, and Cyprus. Once in European territory, the most conspicuous portion of the birds seemed to follow the west coast of the Black Sea in a north-easterly

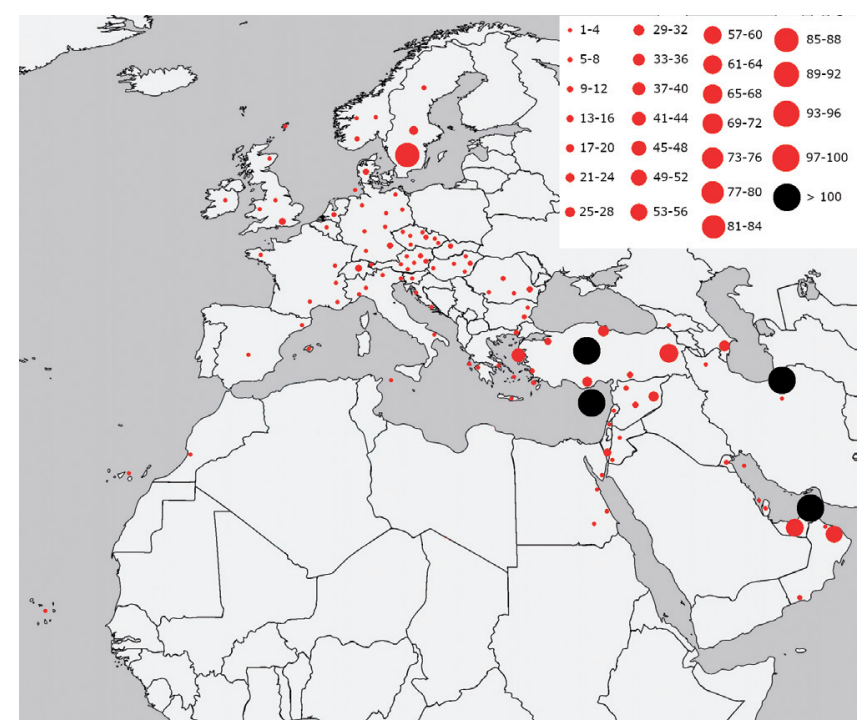

Fig. 20 - Distribution map of citrine wagtail in the spring in the 2000s. / Mappa di distribuzione primaverile della cutrettola testagialla orientale negli anni 2000. direction, while a minority probably reached Greece and southern Italy (Apulia) and then went up north along the two coasts of the Adriatic Sea. In central-northern Europe and Scandinavia (in the areas closest to the breeding sites) the presences were widespread and regular. A migratory flow not comparable to the autumn one also reached the British Isles: both individuals of the second calendar year and adults were observed. To the west, the reports collected outlined an ideal route from the coasts of north-west Africa (Cape Verde, Canary Islands, southern Morocco) that leads birds to the Iberian Peninsula through the Strait of Gibraltar, the Mediterranean coast of Spain and France, and then from the latter towards northern Italy, and through the Rhône valley, to Switzerland to then continue towards the breeding range. Once again the presence of the species was also detected in the central Mediterranean (male and female, island of Pantelleria on $15^{\text {th }}$ May 2008) (Corso et al., 2012). As in the previous decade, once again the citrine wagtail exceptionally reached South Africa, and an individual was observed in Kleinmond (Western Cape Province) on $11^{\text {th }}$ April 2009 (Underhill, 2015).

In the autumn of 2010s (Fig. 21), the trend in centralnorthern Europe confirmed what had already been observed in the previous decade, including the presence of individuals also in the Faroe Islands and Iceland and, in the westernmost areas, the very high prevalence of birds born in the year. On the other hand, the widespread migratory movement that took place in the Balkan area and, above all, along the western coast of the Black Sea, was new. In the Middle East, the accentuation of the migratory movement in the Arabian Peninsula was evident, especially due to the contribution of birds originating from Russia (through the Caucasus), and from the east of the Caspian Sea (through the northeastern regions of Iran). Part of the migrants passed through Egypt and some also reached Ethiopia. Quite extraordinary was the presence of an individual in Zambia (Northern or Muchinga

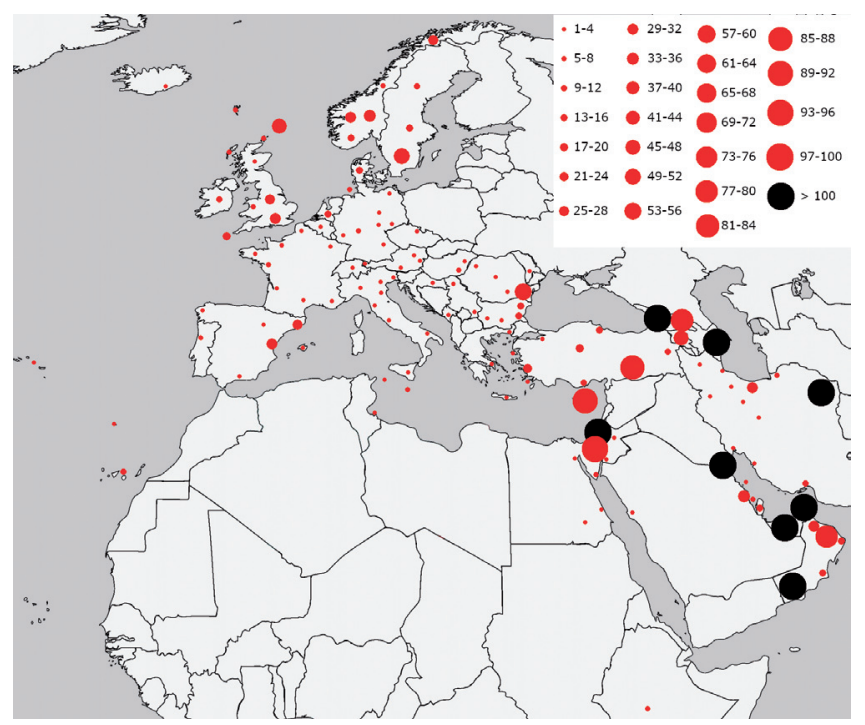

Fig. 21 - Distribution map of citrine wagtail in autumn in the 2010s. / Mappa di distribuzione autunnale della cutrettola testagialla orientale negli anni 2010. 
Province) on $11^{\text {th }}$ November 2011 (Dick van Hoffen in Observation.org, 2020), and also for the date, in South Africa (Tankatara Salt Pans, Eastern Cape Province) on $27^{\text {th }}$ August 2017 (African Bird Club, 2020). As already suggested by the observations in previous decades of citrine wagtail in the Pelagie Islands and Pantelleria, in Italy a further, numerically limited migratory route was consolidated that brought the species from Europe to northern Africa through the central Mediterranean with consequent reporting of a specimen on the island of Jerba (Tunisia) on $22^{\text {nd }}$ September 2010 (Azafzaf et al., 2015). In Western Europe, the migratory route along the Mediterranean coast of the Iberian peninsula seemed consolidated (with possible contributions from both birds coming from the south of France and from individuals that came down from northern Europe along the Atlantic coast of France) towards Africa. The species once again reached the Atlantic islands: Azores (first-winter, Terceira on $14^{\text {th }}$ September 2012) (Vegard Bunes et al. in azoresbs.weebly.com, 2020), Madeira (first-winter, Lugar de Baixo on $10^{\text {th }}$ September 2011) (Correia-Fagundes et al., 2012), and Canary Islands (ten individuals, of which only one adult) (Copete et al., 2015; Gil-Velasco et al., 2017a; 2017b). During the 2010 s, the now consolidated and widespread winter presence of the species throughout the Middle East and Cyprus was confirmed, as well as the regular, albeit quantitatively low, presence in the Horn of Africa and Egypt (Fig. 22). On the other hand, the observation of an individual in Bulgaria (Aldomirovtsi marsh, Sofia Province) on $5^{\text {th }} \mathrm{Feb}-$ ruary 2011 was new (smartbirds.org, 2020). Also in the West, the presence in Europe of the species was confirmed both in the Iberian Peninsula and in the south of France (GBIF, 2020; faune-france.org, 2021), as well as along the Atlantic coast of Africa (Morocco, Canary Island, and Sudan), and for the first time, in Algeria (adult male, Béchar, $10^{\text {th }}$ February 2018) (Mehadji Ali in Observation.org, 2020). During spring migrations in the Middle East, the already known routes to the north-eastern reproductive ar-

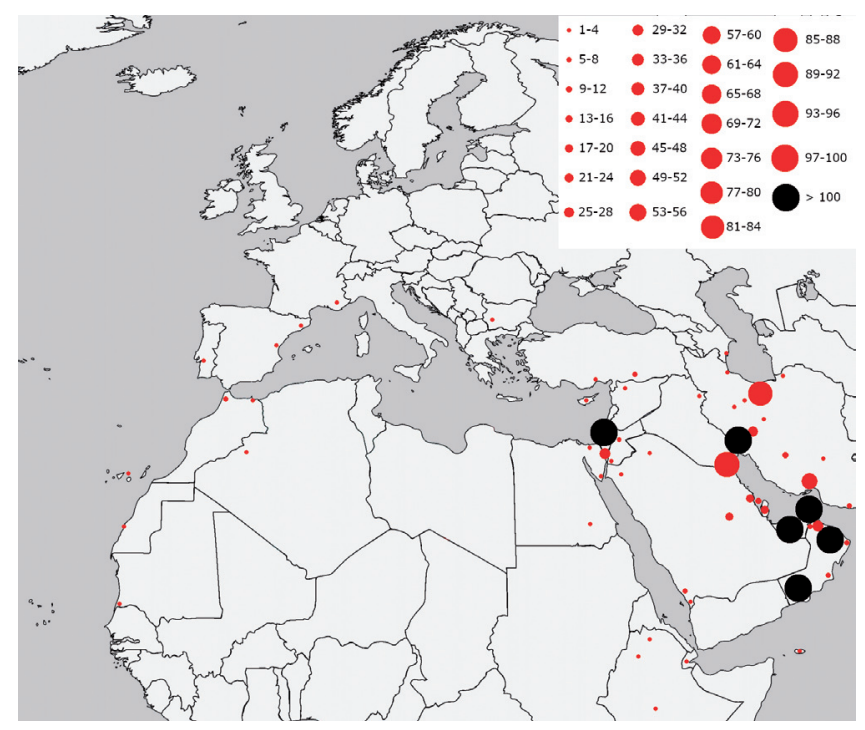

Fig. 22 - Distribution map of citrine wagtail in the winter in the 2010s. / Mappa di distribuzione invernale della cutrettola testagialla orientale negli anni 2010.

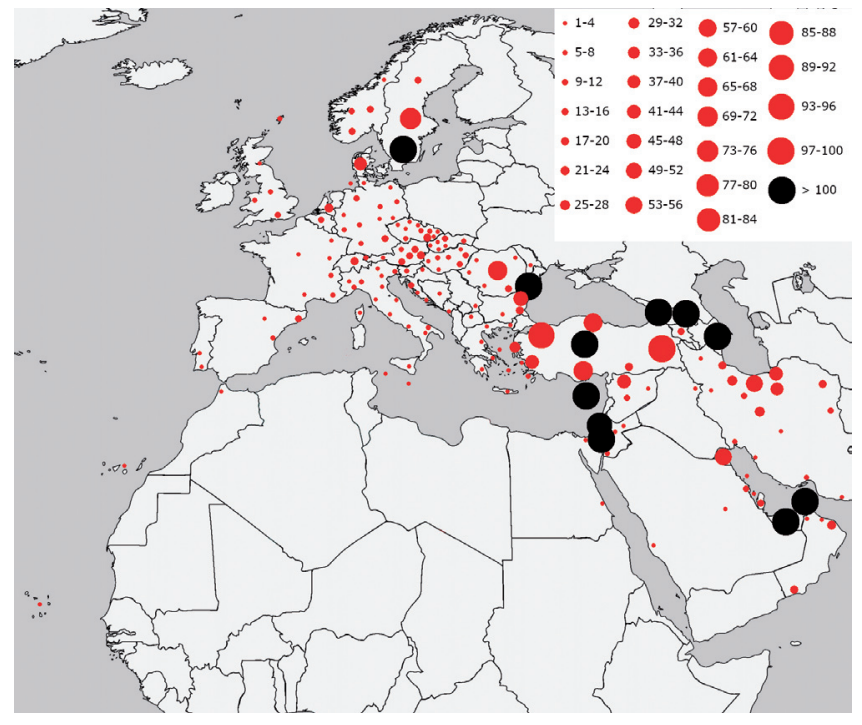

Fig. 23 - Distribution map of citrine wagtail in the spring in the 2010s. / Mappa di distribuzione primaverile della cutrettola testagialla orientale negli anni 2010.

eas were confirmed, especially through the Caucasus area (Fig. 23). It then became evident the assumed importance of the flow which, after crossing Turkey, ascended northwards following the western edge of the Black Sea. More diluted, but still perceptible, was also the path chosen by a minority of birds that, through Greece, traveled north into the Balkan area. In the central Mediterranean, the observations in Malta, Pantelleria and Sicily, together with those distributed throughout the Italian peninsula (Ornitho.it, 2020), definitively confirmed the use of this new route. In the west, the presences in Cape Verde, the Canaries, Morocco, the Iberian Peninsula, and southern France were the logical consequence of what was observed in autumn and winter, that is, the now regular use of this route by the species. Extraordinarily, but no longer surprising, were the observations of citrine wagtail in South Africa: five individuals between 2014 and 2018, between April $14^{\text {th }}$ and May $3^{\text {rd }}$, in four different regions (Western Cape, Eastern Cape, KwaZulu-Natal, and Namibia) (Underhill, 2015; African Bird Club, 2020; GBIF, 2020). The summer presences were completely new: an individual on $17^{\text {th }}$ August 2017 in Tankatara Salt Pans (Eastern Cape) (African Bird Club, 2020) and, an adult on $28^{\text {th }}$ and $29^{\text {th }}$ June 2019 in Pongola Game Reserve (KwaZulu-Natal) (Arthur Brad, Daryl Dell, Niall D. Perrins and Clayton Burne in macaulaylibrary.org, 2020).

The overall trends of the seasonal abundance of the species over the decades in the four geographical areas considered are summarized in the graphs of Fig. 24.

The data collected for Europe fairly faithfully describes the trend of presences in the different seasons over the decades, while it is probable that for the other geographical areas the data are underestimated, this is due to the densities of ornithologists/birdwatchers which are significantly lower than in Europe. As stated in the methods, it is likely that in order to obtain reliable numbers relating to the Middle East and Transcaucasia, the values shown in the graphs must be more than quadrupled. 

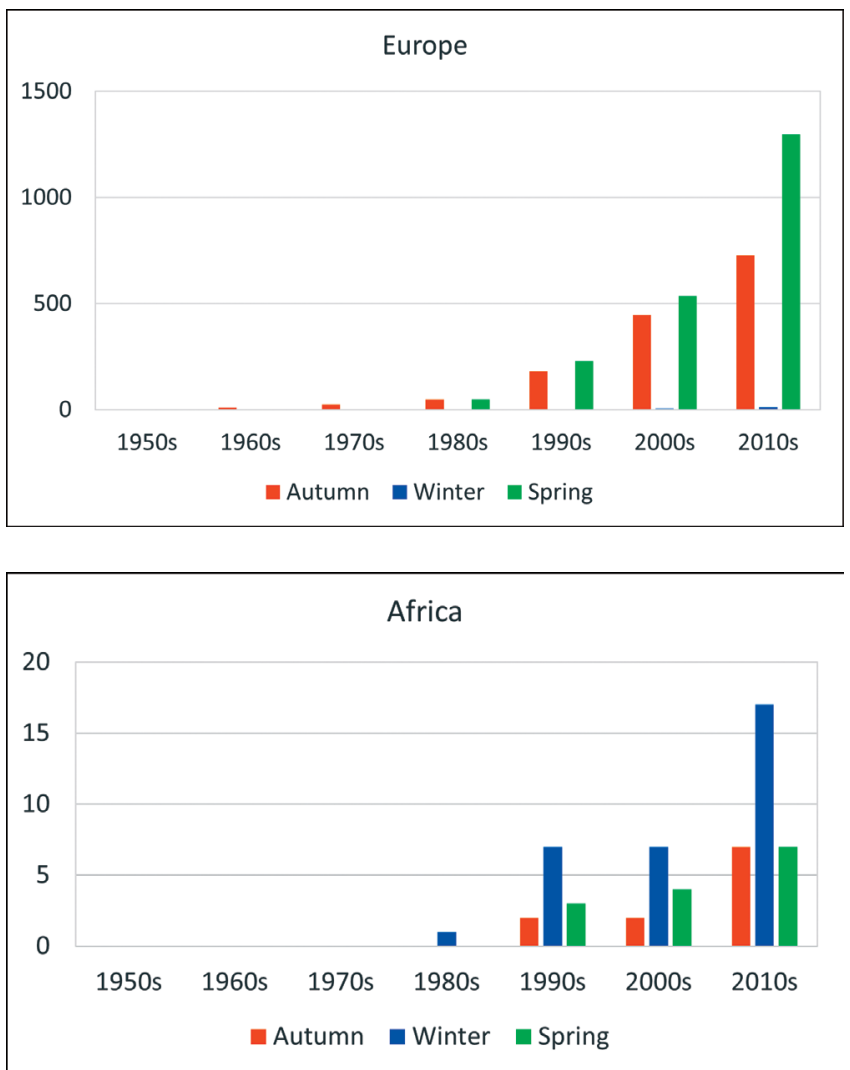
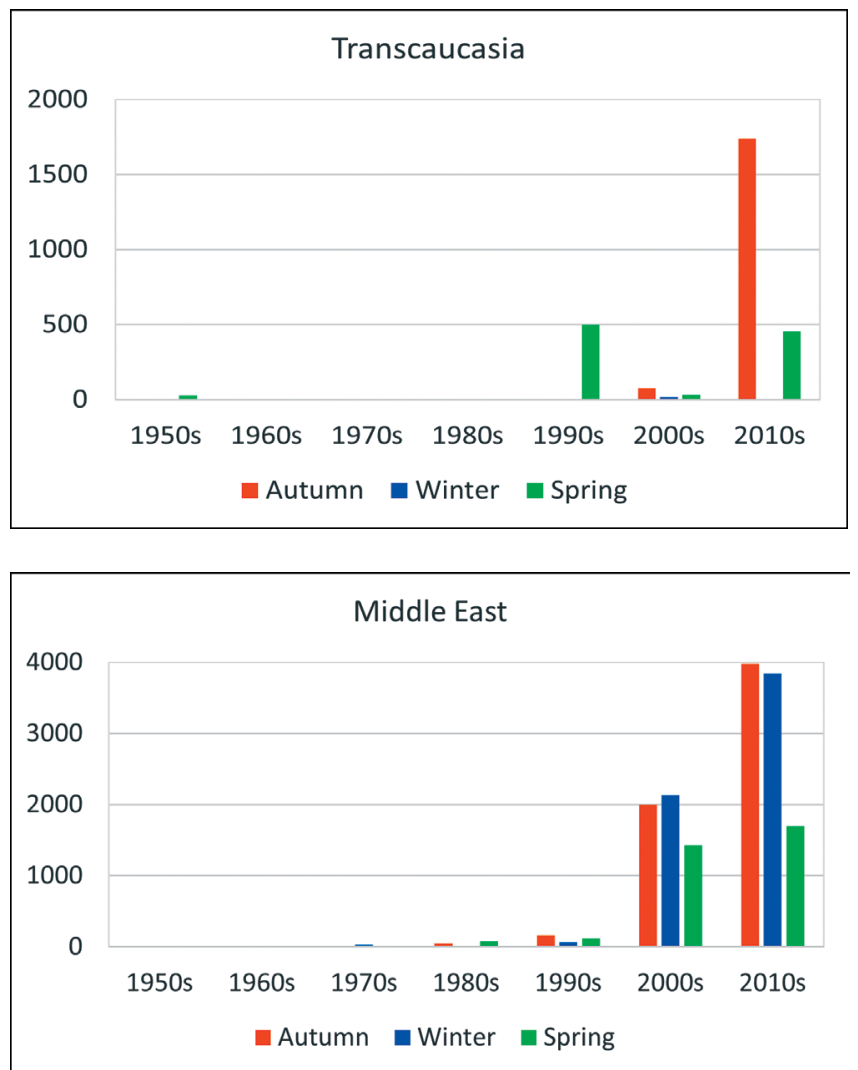

Fig. 24 - Trends in seasonal abundances over the decades in different geographic areas. / Tendenze delle abbondanze stagionali nel cordo dei decenni nelle diverse aree geografiche.

\section{DISCUSSION}

Ornithologists of the late $19^{\text {th }}$-early $20^{\text {th }}$ century agreed in indicating India, southern China, and south-east Asia as the wintering range for the citrine wagtail (Naumann, 1897; Arrigoni degli Oddi, 1902; 1904; Hartert, 1922; Wardlaw-Ramsay, 1923). It was only in the mid-20 $0^{\text {th }}$ century that Dement'ev \& Gladcov (1954) mentioned the occasional presence of the species also in Palestine and Egypt. From the results presented, at the end of the first two decades of the twenty-first century a secondary range in the Middle East is being added to the main Asian wintering area known for the citrine wagtail that is mainly concentrated around the Persian Gulf, in the south of Arabian Peninsula, in the southern part of the Caspian Sea, and in the area between the Red Sea and the Mediterranean Sea. Wintering in the Horn of Africa, West Africa, and southern Europe is still marginal, but tending to increase and in potential future consolidation. In all these areas, albeit with different quantitative scales, there is an evident apparent progressive increase in presences (Fig. 24). But is the increase real or does it depend solely on the largest number of observers? As shown by other authors (Lewington et al., 1991; Dickinson et al., 2012; Maldonado et al., 2015; Hahn et al., 2020), the results may reflect the considerable bias in the effort of observers in space and time. It is important to note that following new knowledge of its identification (Svensson, 1977; Barthel, 1990), the number of records raised considerably for well-watched countries in North and Western Europa, and the increased travel activities in former soviet countries lead to a fuller understanding of the occurrence. However, the amplitude of the samples and the substantial agreement of the trends over the decades in all the areas investigated, lead us to believe that the increases detected are real, even if probably associated with a generalized greater detection effort.

Regarding the Middle East, although there was evidence of the first wintering in the 1970 s, it is very likely that some individuals arrived there already in the previous decades as suggested by their presence in Iraq in the spring of 1945 (Moore \& Boswell, 1956), from the statements of Dement'ev \& Gladcov (1954) and from the autumn and spring reports of the $1960 \mathrm{~s}$. Since the $21^{\text {st }}$ century, more and more northern winters have been observed, particularly in northern Turkey, Azerbaijan, and Iran. In Iraq until 2009, the species was still considered a "Rare winter visitor" (Porter et al., 2010), but already in 2012 it was defined as an "Uncommon winter visitor" (Salim et al., 2012) and in 2015 simply as a "Winter visitor" (Salim \& Porter, 2015).

Although werae had been reported as a breeders in Astrakhan by Buturlin (1907), at the beginning of the $20^{\text {th }}$ century, only from the middle of the same century did the species begin to use the migratory route through the Caucasus to reach the Middle East, at first on an occasional basis (Dement'ev \& Gladcov, 1954; Ochapovsky, 1965) and then in an increasingly regular and evident way (Barthel, 1990; Kinda et al., 2003; Koblik \& Arkhipov, 2014). In particular, the first well documented evidence of the presence of the species in the area is that of Ochapovsky 
(1965) concerning April 1957 while the species migrated together with Motacilla flava and Motacilla alba. On $13^{\text {th }}$ April 1960, the species was also reported in the Krasnodar Territory, and in the same days isolated individuals passed through Komarov (Rostov Oblast) (Ochapovsky, 1965). The accentuation of the presence of the citrine wagtail in Turkey must probably be connected to this route; in fact until the end of the 1970s, the species in this country rarely occurred (Kirwan et al., 2008), but it progressively increased until it settled as a breeder. Already in the late 1980s, north of the Caspian Sea, the species travels regularly in the Volga Delta and Astrakhan region (Barthel, 1990). As noted for many other species (Heiss \& Gauger, 2011; Heiss, 2013; BirdLife International, 2020b), currently the maximum migratory intensity of citrine wagtail in the area is found in the Besh Barmag bottleneck (Azerbaijann) and Batumi bottleneck (Georgia). Both the two bottlenecks consist of narrow coastal plains bounded, respectively, by the Greater Caucasus and the Caspian Sea and the Greater Caucasus and the Black Sea.

In conjunction with the progression of the reproductive area in Western Europe, the migration route in both autumn and spring also expanded westward. In Crimea, not considering some old and uncertain records from the early $19^{\text {th }}$ century and the $1940 \mathrm{~s}$, the first certain observations were in the years between 1976 and 1979 (subspecies werae) with subsequent confirmations in the following decades both in spring and in autumn (in the latter case mainly first-winter individuals) (Kinda et al., 2003). From the end of the 1980s, the western passage of the Black Sea became increasingly intense and regular, as documented, for example, by Schmitz's 1996 observations (Schmitz, 1998).

In the Middle East, all three subspecies are found: werae seems to be the most common, citreola is still present, while calcarata is vagrant (Porter \& Aspinall, 2010; Aspinall \& Porter, 2011; Eriksen \& Porter, 2017; Khaleghizadeh et al., 2017; Zarei et al., 2018).

The subspecies calcarata reaches the Middle East from the east, and nests locally in the highlands of eastern Iran, from Khorasan to Kerman (Kaboli et al. 2016; Khaleghizadeh et al., 2017). It was also recorded over a century ago as a local nesting bird in the highland swamps of Baluchestan and the wet meadows of Sistan (Hüe \& Etchécopar, 1970; Vaurie, 1959; Kaboli et al. 2016). The subspecies winters in lowlands from Southern Afghanistan East to Myanmar (Dement'ev \& Gladkov, 1954; Rasmussen \& Anderton, 2012; Tyler \& Kirwan, 2020). Occurrences in the west of the reproductive range are really scarce: a male in eastern Turkey (south Van marshes) on $17^{\text {th }}-18^{\text {th }}$ May 2011 (Occhiato, 2011), a possible male in Western Anatolia (Çalıs marsh, Fethiye) on $15^{\text {th }}$ June 2011 (Kirwan et al., 2014), a male in Azerbaijan (lagoons of Kizil Agach Bay) on $26^{\text {th }}$ May 2019 (Lawicki \& van den Berg, 2019), and five reports in Oman of which there were three in winter (Al Mouj Golf, Muscat, $27^{\text {th }}$ February 2013; Sun Farms, Sohar, $13^{\text {th }}$ February- $1^{\text {st }}$ March 2014; A1 Mouj Golf, Muscat, 25 th $F$ February 2015), one in autumn (Khawr Rawri, Salalah, $9^{\text {th }}$ November 2013), and one in spring (Sun Farms, Sohar, $5^{\text {th }}$ April 1990), but it is possible that calcarata in Oman is more regular than the five records indicate (Jens Eriksen, pers. com.).
The citreola subspecies probably reaches and leaves the Middle East following mainly a route east of the Caspian Sea. However, there are also reports for the Caucasus area both in Azerbaijan (Koblik et al., 2014) and, more recently, in Georgia (Filip Collet, André Lagendijk, Tom Damm, Rob Struyk, Zuka Gurgenidze, Tina Leguijt, Maurice de Graaf, Jos van Oostveen \& Han Buckx in Observation. org, 2020); this could justify the reporting of some individuals attributable to this subspecies in eastern Turkey (East Anatolia) (Kirwan et al., 2008). Since its presence as a migrant in European Russia is excluded (Kalyakin, 2014; Red'kin, 2020; Red'kin \& Kalyakin, 2020), it probably does not transit west of the Black Sea. This subspecies winters mainly in the southern part of the Arabian Peninsula, in particular in Oman (Jens Eriksen, pers. com.). Since the last decade of the $20^{\text {th }}$ century, during the spring migration it was reported in Israel (Shirihai, 1996), Jordan (Duquet, 2001), Cyprus (Colin Richardson, pers. com.) and probably on the Lesbos island (Greece) (Obervation.org, 2020).

The subspecies werae, in addition to nesting in Turkey, certainly migrates through the Caucasus and is probably the only subspecies that meets in spring and autumn west of the Black Sea. It winters widely in all areas occupied by the species in the Middle East (Porter \& Aspinall, 2010; Jens Eriksen, pers. com.). In the Balkan area, a weak migratory flow probably already existed in the 1970s and has gradually intensified. The fact that up to the 1990s the observations in the Balkan area and in the eastern Mediterranean were more frequent in spring than in autumn may suggest more eastern migration routes in autumn and more western in spring, however a difficulty in identifying them especially in autumn can not be excluded. In fact, it should be remembered that the main identification guides in use in those decades (Peterson et al., 1954; Bruun \& Singer, 1970; Heinzel et al., 1972) provided only approximate descriptions or figures of the species, which lacked particularly for non-breeding dress and for first-winter. Following some studies devoted mainly to the distinctive characters of immature citrine wagtails (Svensson, 1977; Kapanen, 1979; Brown \& Gordon, 1985; Burns, 1986; Jännes \& Lammin-Soila, 1989), the first exhaustive treatments of the different dress, even at the subspecies level, were made in the year 1990 (Barthel, 1990; Malling Olsen, 1990).

In Western Europe, before the westward expansion of the breeding range, the presence of the species was quite sporadic, with the exclusive appearance of first-winter individuals in the autumn-winter period in the North Sea (Heligoland archipelago). In the second half of the $20^{\text {th }}$ century, observations increased, but continued to be characterized by the almost exclusive presence of first-winter individuals in post-fledging dispersal. To the north, as early as the 1970s, they went as far as Iceland, and to the south, starting from the $1980 \mathrm{~s}$, they traveled routes that took them along the southern coast of Spain and France. The wintering of an individual in Sicily in 1974 and subsequent migratory movements in Italy suggest that a new migratory route through the central Mediterranean was also being generated in those years. Wintering in Europe was subsequently confirmed in the southern part of the continent (Portugal, Spain, France, Bulgaria) and, sporadically, also in Scandinavia. We believe that the citreola 
subspecies may be present, although rarer than the werae, in Scandinavia and Western Europe during migration, especially in late autumn. A wintering bird from Sweden showed characteristics only compatible with citreola, as have a number of September vagrants to South Sweden (large size, long tail, extensive grey flanks).

The route along the French and Spanish coasts of individuals, probably in mixed flock with Motacilla flava, led the species, as early as the 1980s, to winter in West Africa (Morocco, Algeria, Mauritania, Senegal). The presences in East Africa can probably be interpreted as a natural continuation of the journey for some birds that arrive in the Arabian Peninsula from the north and east. These presences, apparently, are numerically very scarce, but they have been repeated for three decades and could be underestimated.

The spring observations and the presences during the austral winter recorded in South Africa are to be considered cases of reverse migrations of individuals who had spent the boreal winter in Africa. Similar cases are also known in Australia regarding individuals wintering in Southern Asia: a subject at the beginning of July 1962 in New South Wales (McGill, 1963), an individual on $28^{\text {th }}$ $29^{\text {th }}$ May 1987 in South Australia (Holder et al., 1988), a female on $5^{\text {th }}$ May 2009 in Christmas Island (James \& Mcallan, 2014), and most recently, an individual on $26^{\text {th }}$ July 2020 in Katherine (Northern Territory) (Mark Gardner, Peter Kyne \& Tom Tarrant in eBird, 2020).

The citrine wagtail was also encountered as an accidental winter visitor in America: a bird was found on $31^{\text {st }}$ January and $1^{\text {st }}$ February 1992 at the Starkville Sewage Ponds in Oktibbeha County, Mississippi (USA) (DeBenedictis et al., 1994), and a first-winter individual was observed in British Columbia (Canada) near the Courtenay River Estuary between $15^{\text {th }}$ November 2012 and $25^{\text {th }}$ March 2013 (Toochin, 2019).

\section{CONCLUSIONS}

Fiedler (2003) stated that the Citrine Wagtail, despite expanding its breeding range westward into Europe, still winters in India and Southeast Asia. This statement is true only when referring to the main part of the overall population of the species, in fact, the results of this study highlight that Motacilla citreola has expanded the wintering range farther to the west than in the past.

Especially in the activation of the most western routes, a fundamental role was played by the phenomenon of post-fledging dispersal (or explorative migration) (Baker, 1978; Newton, 2008), manifested by young who, as also observed in other Asian passerines (e.g., Pallas's warbler Phylloscopus proregulus, yellow-browed warbler Phylloscopus inornatus, pine bunting Emberiza leucocepha$l o s)$, in autumn they moved in different directions than the typical migratory route of their species. Autumn vagrancy occurs primarily as the result of an inherited genetic mutation or other anomalies relating to the bird's magnetic sensibilities which affect the navigation systems of an unknown proportion of the population (Vinicombe \& Cottridge, 1996; Gilroy \& Lees, 2003; Newton, 2008; Lees \& Gilroy, 2009). As hypothesized by other authors
(Gilroy \& Lees, 2003; Bruderer et al., 2008; de Juana, 2008), it is possible that during these dispersive phases, some individuals have found, in new territories for the species, climatic and environmental conditions not only favorable for wintering, but also advantageous (higher survival rates), and then returned to the breeding range the following spring. These trailblazers, by transmitting their own genetic makeup, have favored the consolidation over time of new migratory behaviors for an increasingly large fraction of the population. That the phenomenon is now limited to a minority part of the population of the werae subspecies that colonized eastern Europe and to an equally minority portion of the northernmost subspecies (citreola) is shown by the numbers. In fact, excluding Russia, it is estimated that the pairs of breeding werae in the newly colonized countries (Finland, Estonia, Latvia, Lithuania, Belarus, Poland, Ukraine, Slovakia, Georgia, Armenia, Turkey) are between 11,600 and 22,900 (BirdLife International, 2015). Studies conducted in Poland showed that the most common clutch-size was 5 eggs, hatching success was $55.3 \%$, and on average, 2.6 chicks hatched in a nest, the final fledging success reached $38.1 \%$, and on average, 1.8 chicks left the nest (Ściborska, 2004). At the end of the breeding season it can therefore be estimated that in the countries indicated above there are from 44,000 to 87,000 individuals. It is plausible to think that the individuals belonging to the subspecies werae that reach and overwinter in the Middle East are a part of this population. They are also joined by individuals belonging to the citreola subspecies that migrate following more eastern routes both east and west of the Caspian Sea. It is impossible to accurately calculate the total number of individuals of citrine wagtails currently (2020) wintering in the Middle East, however we know that, especially in the south of the Arabian Peninsula, the species is now abundant and can also be encountered in flocks of hundreds. For example, in Oman the largest flock was of 250 birds from Sun Farms (Fig. 25), Sohar, on $30^{\text {th }}$ October 2003 and 200 from Khawr Taqah in southern Oman on $1^{\text {st }}$ November 2004 (Jens Eriksen, pers. com.). Based on the data we have collected, we can estimate that overall the Middle East could host 2,000-4,000 citrine wagtails in winter, mostly werae. These numbers make us understand that most of the individuals originating in the newly colonized countries still migrate to the east, as is the case for the citreola population, however the Middle East and the neighboring Horn of Africa are progressively increasing in relevance as an additional area for the wintering of the species as a whole. Similarly, if in Europe the expansion of the breeding range towards the west continues in the future, West Africa, reached through Gibraltar, could become important as additional wintering areas. In analogy with what is being observed for the western yellow wagtail Motacilla flava (Ferlini, 2020), Europe itself is also becoming part of the wintering range of the species. In fact, there is an increase in cases of wintering not only in the south of the continent, but there is also a progression towards the north: in France two individuals wintered in Arles from $10^{\text {th }}$ January to the end of February 2020 (Daniel De Sousa et al. in eBird, 2020) and one was present on $31^{\text {st }}$ December 2020 along the Atlantic coast in Cham- 


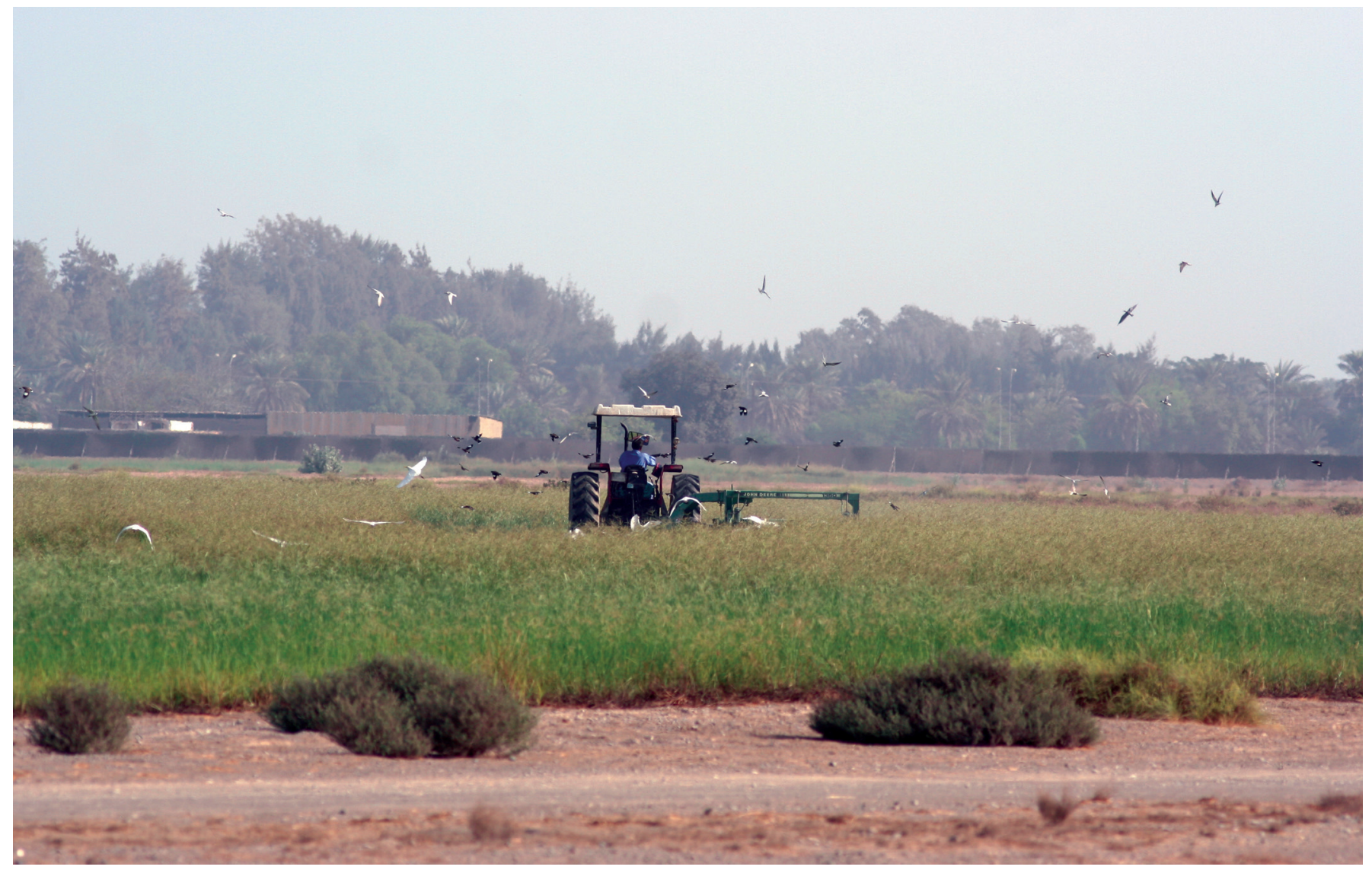

Fig. 25 - Sun Farms, Sohar, Oman, October 2008. It is a large dairy farm with forage fields that attracts a very wide variety of migrants and winter visitors (including Motacilla citreola). / Sun Farms, Sohar, Oman, ottobre 2008. È un grande caseificio con campi di foraggio che attraggono una varietà molto ampia di migranti e visitatori invernali (inclusa Motacilla citreola). (Photo / Foto: Paolo Marotto).

pagné-les-Marais (Pays de la Loire) (Pierre Foulquie in faune-france.org, 2021).

Like Motacilla citreola, other species, that have expanded the breeding range in Europe coming from the East, have also shown the ability to adapt their migratory routes to the new situations. An evident example is represented by the pallid harrier Circus macrourus: starting from the early years of the $21^{\text {st }}$ century, in conjunction with the expansion of the breeding range in Finland, the presence in Western Europe has increased during migrations and part of the population now reaches West Africa via Gibraltar (Terraube, 2020; Terraube et al., 2021).

These examples show that migratory species are endowed with remarkable plasticity at the population scale; in fact, they are able to adapt both the migratory routes and the wintering ranges to the variations of the breeding ranges.

\section{Acknowledgements}

We heartedly thank Neil Baker (Tanzania Bird Atlas), the Bird Protection and Study Society of Serbia, the British Trust for Ornithology (specially Dawn Balmer, Neil Calbrade, and the BirdTrack team), Joost Brouwer (Manager West African Bird DataBase), John Caddick (African Bird Club), DOPPS - BirdLife Slovenija (spe- cially Urška Koce), Robert Dowsett, Jens Eriksen (Oman Bird Recorder), Jacques Franchimont, Sam Gobin (samgobin.nl), Tibor Hadarics, the Hellenic Rarities Committee (specially George Handrinos and Nikos Probonas), the Hungarian Bird and Nature Conservation Association (specially Csaba Lendvai), Mikhail Kalyakin, Guy M. Kirwan, Tom Lindroos, Paolo Marotto (Gruppo Piemontese Studi Ornitologici "F.A. Bonelli"), David Murdoch, Silas Olofson, Yoav Perlman (Israel Ornithological Center), Jessica Peruzzo, Lorenza Piretta, Gloria Ramello, Nigel Redman, Colin Richardson (Ornithological Society of the Middle East), the Slovenian Rarities Committee (specially Mitja Denac, and Jurij Hanžel), the Schweizerische Avifaunistische Kommission (specially Bernard Volet), Szabolcs Gál (Hungarian Rarities Committee), the Societatea Ornitologică Română / BirdLife Romania (specially Cristi Domșa), Vincent van der Spek, Mirjan Topi (Birding Albania), Alfred Trnka (University of Trnava), Iliya Ukolov, Les Underhill (Biodiversity \& Development Institute, South Africa), Olga Voltzit, and Alexander Yakovlev for the information and/or materials they have kindly supplied. Special thanks to the Editor and to the anonymous referees for the critical revision of the text and for the valuable suggestions. We are also grateful to Kelsey Horvath for the revision of English text. 


\section{REFERENCES}

Abuladze A. V. \& Edisherashvili G. V., 2018 - An Annotated CheckList of Passerine Birds of the South Georgian Highland. XXVI Proceedings of the Institute of Zoology: 16-32.

African Bird Club, 2020 - South Africa News. African Bird Club. $<$ https://www.africanbirdclub.org/countries/South-Africa/news $>$ (retrieved in November 2020).

Alström P., Mild K. \& Zetterström B., 2003 - Pipits \& Wagtails of Europe, Asia and North America. Identifications and Systematics. Christopher Helm, London.

Ananian V. \& Busuttil S., 2002 - The first breeding records of Citrine Wagtail Motacilla citreola and Savi's WarbIer Locustella luscinioides in Armenia. Sandgrouse, 24 (1): 52-53.

Anthes N., Götz H. \& Handschuh M., 2019 - Expanding north? Putting the first German breeding record of Black-headed Bunting Emberiza melanocephala into context. Vogelwelt, 139: 31-38.

Arrigoni degli Oddi E., 1902 - Atlante Ornitologico. Uccelli Europei con Notizie d'Indole Generale e Particolare. Ulrico Hoepli, Milano.

Arrigoni degli Oddi E., 1904 - Manuale di ornitologia italiana; elenco descrittivo degli uccelli stazionari o di passaggio finora osservati in Italia. Ulrico Hoepli, Milano.

artportalen.se, 2020 - Motacilla citreola. $<$ https://artportalen.se/> (retrieved in December 2020).

artsobservasjoner.no, 2020 - Motacilla citreola. $<\mathrm{https}$ ://www.artsobservasjoner.no/> (retrieved in December 2020).

Aspinall S. \& Porter R. F., 2011 - Birds of the United Arab Emirates. Christopher Helm, London.

Azafzaf H., Feltrup Azafzaf C., Dlensi H. \& Isenmann P., 2015 - Nouvelles donnees sur l'avifaune de Tunisie (2005-2014). Alauda, 83 (1): 7-28

azoresbs.weebly.com, 2020 - Azores Bird Sightings. < https://azoresbs. weebly.com/latest-sightings.html $>$ (retrieved in December 2020).

Baker R. R., 1978 - The Evolutionary Ecology of Animal Migration. Hodder and Stoughton, London.

Balmer D. \& Betton K. F. (eds.), 2008 - Around the Region. Sandgrouse, 30 (1): 14-21.

Barthel P. H., 1990 - Hinweise zur Bestimmung der Zintronenstelze Motacilla citreola. Limicola, 4: 149-182.

Baumanis J., Jackson P. \& Serebryakov V. V., 1997 - Citrine Wagtail. In: The EBCC atlas of European breeding birds: their distribution and abundance. Hagemeijer W. J. M. \& Blair M. J. (eds.). Poyser, London.

Bergier P., Franchimont J., Thévenot M. \& Moroccan Rare Birds Committee, 2000 - Rare birds in Morocco: report of the Moroccan Rare Birds Committee (1995-1997). Bulletin African Bird Club, 7 (1): 18-28.

Berthold P., 1998 - Vogelwelt und Klima: gegenwärtige Veränderungen. Naturwissenschaftliche Rundschau, 51: 337-346.

Berthold P., 2001 - Bird migration. A general survey. Second Edition. Oxford University Press, Oxford, UK.

BirdLife International, 2015 - Motacilla citreola (Citrine Wagtail). European Red List of Birds Supplementary Material. $\quad<$ http://datazone.birdlife.org/userfiles/file/Species/erlob/ supplementarypdfs/22718379_Motacilla_citreola.pdf> (retrieved in December 2020).

BirdLife International, 2016-Motacilla citreola. The IUCN Red List of Threatened Species 2016: e.T22718379A88052549 https://dx.doi. org/10.2305/IUCN.UK.2016-3.RLTS.T22718379A88052549.en (retrieved in March 2019).

BirdLife International, 2020a - Species factsheet: Motacilla citreola. $<$ http://www.birdlife.org $>$ (retrieved in April 2020).

BirdLife International, 2020b - Batumi Bottleneck. <https://www. birdlife.org/europe-and-central-asia/projects/batumi-bottleneck> (retrieved in December 2020).

Brichetti P. \& Fracasso G., 2007 - Ornitologia Italiana. Vol. 4. Alberto Perdisa Editore.

Branch B., 1998 - Citrine Wagtail a spectacular first. Africa: Birds \& Birding, 3 (3): 15.

Brooks D. J., Evans M. I., Martins R. P. \& Porter R. F., 1987 - The status of birds in North Yemen and the records of OSME expedition in autumn 1985. Sandgrouse, 9: 4-66.
Brown A. \& Gordon P. R., 1985 - Head pattern of immature Citrine Wagtail. British Birds, 78: 196.

Bruderer B., Salewski V. \& Liechti F., 2008 - Gedanken zur Evolution des Vogelzuges. Der Ornithologische Beobachter, 105 (2): 165177.

Bruun B. \& Singer A., 1970 - The Hamlyn Guide to Birds of Britain and Europe. The Hamlyn Publishing Group Limited.

Burns P. F., 1986 - Identification problems with immature Citrine Wagtails. British Birds, 79: 464-468.

Buturlin S. A., 1907 - Budytes citreola werae nov. subsp. Ornithologische Monatsberichte, 15: 197-198.

Carlotto L., Fracasso G. \& Grossele A., 1994 - Considerazioni su una nuova osservazione di Cutrettola testagialla orientale, Motacilla citreola, in Italia. Rivista Italiana di Ornitologia, 64 (2): 28-32.

Copete J. L., Lorenzo J. A., Amengual E., Bigas D., Fernandez P., Lopez-Velasco D., Rodríguez G. \& García-Tarrasón M., 2015 - Observaciones de aves raras en España, 2012-2013. Ardeola, 62 (2): 453-508.

Correia-Fagundes C., Romano H., Zino F. \& Biscoito M., 2012 - Additions and corrections to the 2010 checklist of the birds of the archipelagos of Madeira and the Selvagens. Boletim do Museu Municipal do Funchal (História Natural), 61: 23-28.

CHN (Comité d'Homologation National), 2020 - Bergeronnette citrine (Citrine Wagtail) Motacilla citreola. <http://www.chn-france.org/ chn_donnees.php $>$ (retrieved in September 2020).

Clements J. F., Schulenberg T. S., Iliff M. J., Billerman S. M., Fredericks T. A., Sullivan B. L. \& Wood C. L., 2019 - The eBird/Clements Checklist of Birds of the World: v2019.

Corso A., Penna V., Gustin M. \& Maiorano I., 2012 - Annotated checklist of the birds from Pantelleria Island (Sicilian Channel, Italy): a summary of the most relevant data, with new species for the site and for Italy. Biodiversity Journal, 3 (4): 407-428.

Cox S. \& Inskipp T., 1978 - Male citrine wagtail feeding young wagtails in Essex. British Birds, 71: 209-213.

Cramp S. (ed.), 1988 - The birds of the Western Palearctic. Vol. 5. Tyrant Flycatchers to Thrushes. Oxford University Press, Oxford.

Cuervo J. J. \& Møller A. P., 2013 - Temporal Variation in Population Size of European Bird Species: Effects of Latitude and Marginality of Distribution. PLoS ONE, 8 (10): e77654. <https://doi. org/10.1371/journal.pone.0077654>

DAK, 2014 - Seltene Vogelarten in Deutschland 2013. Deutsche Avifaunistische Kommission: 2-39. <https://www.dda-web.de/downloads/ publications/statusreports/svid 2013 seltenheitenbericht.pdf $>$

Danford C. G. \& Harvie Brown J. A., 1875 - The birds of Transylvania. Part II. The Ibis, 5: 291-312.

Davies C. \& Sharrock J. T. R., 2000 - The European Bird Report. Passerines. British Birds, 93: 415-427.

DeBenedictis P., Dittmann D. L., Dunn J. L., Garrett K., Lasley G., Tingley S. \& Tobish, T., 1994 - ABA 1994 Checklist Report. Birding, 26 (5): 367-368.

de Juana E., 2008 - Where do Pallas's and yellow-browed warblers (Phylloscopus proregulus, Ph. inornatus) go after visiting northwest Europe in autumn? An Iberian perspective. Ardeola, 55 (2): 179-192.

de Juana E. \& el Comité de Rarezas de la Sociedad Española de Ornitología, 2002 - Observaciones homologadas de aves raras en España, año 2000. Ardeola, 49 (1): 141-171.

Dement'ev G. P. \& Gladkov N. A. (eds.), 1954 - Ptitsy Sovyet Soyuza. [The birds of the Soviet Union]. Vol. 5. Sovetskaya Nauka, Moskva.

Dickinson J. L., Shirk J., Bonter D., Bonney R., Crain R. L., Martin J., Phillips T. \& Purcell K., 2012 - The current state of citizen science as a tool for ecological research and public engagement. Frontiers in Ecology and the Environment, 10 (6): 291-297.

Dies J. I., Lorenzo J. A., Gutiérrez R., García E., Gorospe G., MartíAledo J., Gutiérrez P. \& Vidal C., 2007 - Observaciones de aves raras en España, 2005. Ardeola, 54 (2): 405-446.

Dobrota M. \& Topercer J. Jr., 1998 - Citrine wagtail Motacilla citreola breeding in Slovakia. Biologia, 53: 679-684

Draaijer L. \& Slaterus R., 2012 - Gemengd broedgeval van Citroenkwikstaart en Gele Kwikstaart bij Zeewolde in 2011. Dutch Birding, 34 (2): 85-91. 
Dresser H. E., 1871-1881 - A history of the birds of Europe: including all the species inhabiting the western palaearctic region. Volume III. Published by the Author, London.

DSK, 2008 - Seltene Vogelarten in Deutschland von 2001 bis 2005. Limicola, 22: 249-339.

Duquet M., 2001 - Jordan Trip Report 25 March to 1 April 2001. <https://www.osme.org/trip-reports/jortrip7/> (retrieved in September 2020).

Dutch Montagu's Harrier Foundation, 2017 - The Pallid Harrier, a new breeding species for the Netherlands. Nature Today. $<$ https://www.naturetoday.com/intl/en/nature-reports/message/?msg=23620\#: :text $=14 \% 2 \mathrm{DJUL} \% 2 \mathrm{D} 2017 \% 20 \% 2 \mathrm{D} \% 20 \mathrm{The}$, the $\% 20 \mathrm{Dutch} \% 20 \mathrm{Mon}-$ tagu's\%20Harrier\%20Foundation> (retrieved in September 2020)

eBird, 2020 - Motacilla citreola. <https://ebird.org/> (retrieved in December 2020).

Erdqvist J., 1979 - Citronärlehane matar ungar i Jämtland 1977. Vår Fågelvärld, 38 (1): 47.

Eriksen J. \& Porter R. F., 2017 - Birds of Oman. Christopher Helm, London.

European Environment Agency, 2017 -Landscapes in transition. An account of 25 years of land cover change in Europe. European Environment Agency, Denmark, 10.

Farnsworth S. J., Coomber R. F., Jones P., Madge S. C., Webb R. \& Witherick M., 2000 - Recent observations of some bird species previously considered uncommon or rare in Ethiopia. Bulletin African Bird Club, 7 (1): 34-46.

faune-france.org, 2021 - Motacilla citreola. <https://www.faunefrance.org/> (retrieved in February 2021).

Feranec J., Jaffrain G., Soukup T. \& Hazeu G., 2010 - Determining changes and flows in European landscapes 1990-2000 using CORINE land cover data. Applied Geography, 30: 19-35.

Ferlini F., 2020 - Wintering range of western yellow wagtail Motacilla flava in Africa and Europe in a historical perspective. Rivista Italiana di Ornitologia. Research in Ornithology, 90 (1): 3-39.

Fiedler W., 2003 - Recent changes in migratory behaviour of birds: A compilation of field observations and ringing data. In: Avian migration. P. Berthold, E. Gwinner \& E. Sonnenschein (eds). Springer, Berlin: 21-38.

Gätke H., 1895 - Heligoland as an ornithological observatory; the result of fifty years' experience. David Douglas, Hedimburg.

GBIF.org, 2020 - Motacilla citreola Pallas, 1776. $<$ https://www.gbif. $\mathrm{org} / \mathrm{species} / 2490307>$ (retrieved from April to November 2020).

Gerlach B., Dröschmeister R., Langgemach T., Borkenhagen K., Busch M., Hauswirth M., Heinicke T., Kamp J., Karthäuser J., König C., Markones N., Prior N., Trautmann S., Wahl J. \& Sudfeldt C., 2019 - Vögel in Deutschland. Übersichten zur Bestandssituation. DDA, $B f N, L A G V S W$, Münster.

Gill F. \& Donsker D. (eds.), 2020 - IOC World Bird List (v 10.1). $<$ https://doi.org/10.14344/IOC.ML.10.1 > <http://www.worldbirdnames.org/> (retrieved in September 2020)

Gil-Velasco M., Rouco M., Ferrer J., García-Tarrasón M., García-Vargas F. J., Gutiérrez A., Hevia R., López F., López-Velasco D., Ollé À., Rodríguez G., Sagardía J. \& Salazar J. A., 2017a - Observaciones de aves raras en España, 2014. Ardeola, 64 (1): 161-235.

Gil-Velasco M., Rouco M., Ferrer J., García-Tarrasón M., García-Vargas F. J., Gutiérrez A., Hevia R., López F., López-Velasco D., Ollé À., Rodríguez G., Sagardía J. \& Salazar J. A., 2017b - Observaciones de aves raras en España, 2015. Ardeola, 64 (2): 397-442.

Gilroy J. J. \& Lees A. C., 2003 - Vagrancy theories: Are autumn vagrants really reverse migrants? British Birds, 96 (9): 427-438.

Glutz von Blotzheim U. N., 1997 - Erste Brut der Zitronenstelze Motacilla citreola in der Schweiz und aktueller Stand der Arealexpansion. Der Ornithologischer Beobachter, 94: 347-352.

Glutz von Blotzheim U. N. \& Bauer K. M., 1985 - Handbuch der Vögel Mitteleuropas. Vol. 10/II Passeriformes (1. Teil). AULAVerlag, Wiesbaden.

Grant P. J., 1988 - Citrine Wagtail on Mallorca in April 1987. Dutch Birding, 10 (2): 90.

Grant S. \& Marks B., 2020 - Field Museum of Natural History (Zoology) Bird Collection. Version 14.19. Field Museum. Occurrence dataset $<$ https://doi.org/10.15468/exkxdx $>$ (accessed via GBIF.org on 24-03-2021).
Gruwier C., Claerebout S. \& Portier B., 2001 - Bergeronnette citrine Motacilla citreola à Dakar: première mention pour le Sénégal. Bulletin African Bird Club, 8 (2), 139-140.

Hahn S., Alves J. A., Bedev K., Costa J. S., Emmenegger T., Schulze M., Tamm P., Zehtindjiev P.\& Dhanjal-Adams K. L., 2020 - Range-wide migration corridors and non-breeding areas of a northward expanding Afro-Palaearctic migrant, the European Bee-eater $\mathrm{Me}$ rops apiaster. Ibis, 162: 345-355.

Hampe A., Heinicke T. \& Helbig A. J., 1996 - Erste brut der Zitronenstelze Motacilla citreola in Deutschland. Limicola, 10: 311-316.

Harber D. D. \& the Rarities Committee, 1965 - Report on rare birds in Great Britain in 1964. British Birds, 58 (9): 353-72.

Harber D. D., Swaine C. M. \& the Parities Committee, 1963 - Report on rare birds in Great Britain in 1962. British Birds, 56 (11): 393409.

Hartert E., 1922 - Die Vögel der paläarktischen Fauna systematische Übersicht der in Europa, Nord-Asien und der Mittelmeerregion vorkommenden Vögel. Vol. 1. R. Friedländer \& Sohn, Berlin.

Hazevoet C. J., 2010 - Sixth report on birds from the Cape Verde Islands, including records of 25 taxa new to the archipelago. Zoologia Caboverdiana, 1 (1): 3-44.

Heinzel H., Fitter R. \& Parslow J., 1972 - The Birds of Britain and Europe With North Africa and The Middle East. Collins. London.

Heiss M., 2013 - The importance of Besh Barmag bottleneck (Azerbaijan) for Eurasian migrant birds. Acta Ornithologica, 48: 151-164.

Heiss M. \& Gauger K., 2011 - Coastal Bird Migration at the Caspian Shore of the Azerbaijan Republic in October 2007. Podices, 6 (1): 59-71.

Hellwig N., Walz A. \& Markovic D., 2019 - Climatic and socioeconomic effects on land cover changes across Europe: Does protected area designation matter? PLOS ONE, 14 (7): e 0219374. <https:// doi.org/10.1371/journal.pone.0219374>

Henry M., 2018 - The changing status of the Pallid Harrier in Western Europe. British Birds, 111: 744-760.

Hingston M. N., Casement M. \& Howe S., 2005 - Land birds over the Caspian Sea, 1997-1998. Sea Swallow, 54: 44-59.

Holder A., Figwer K., Carpenter G. \& Kernot R., 1988 - Two further sight records of Motacilla Wagtails in South Australia. South Australian Ornithologist, 30 (6): 166-168.

Hüe F. \& Etchécopar R. D., 1970 - Les oiseaux du Proche et du Moyen Orient. Éditions N Boubée et Cie, Paris.

Inskipp T., 1979 - Recent west Palearctic records of Citrine Wagtail. British Birds, 72: 44.

Isenmann P., 1990 - Some recent bird invasions in Europe and the Mediterranean Basin. In: Biological Invasions in Europe and the Mediterranean Basin. di Castri F., Hansen A. J. \& Debussche M. (eds.). Kluwer Academic Publisher, Dordrecht: 245-261.

Jacoby H., 1964 - Eine Zitronenstelze (Motacilla citreola) am Bodensee. Journal of Ornnithology, 105: 90-91.

James D. J. \& Mcallan I. A. W., 2014 - The birds of Christmas Island, Indian Ocean: A review. Australian Field Ornithology, 31(Supplement): S1-S175.

Jännes H. \& Lammin-Soila M., 1989 - Nuorten sitrunnavästäräkkien Motacilla citreola erottaminen "harmaista" keltavästäräkeistä Motacilla flava. Lintumies, 24: 108-113.

Jubete Tazo F. \& Mougeot F., 2019 - Primera cita de reproducción confirmada del aguilucho papialbo en España. Quercus, 402: 12-15.

Kaboli M., Aliabadian M., Touhidifar M., Hashemi A., Musavi B. \& Roselaar C. C., 2016 - Atlas of Birds of Iran. Jahad daneshgahi, Kharazmi Branch.

Kalyakin M. V. (ed.), 2014 - Полный определитель всех видов птиц европейской части России (Complete guide to all bird species in the European part of Russia). Vol. 3 Фитон XXI, Москва.

Kanuscak P., 1977 - Die Zitronenstelze (Motacilla citreola Pall.) ein neues Mitglied der Avifauna in der Tschechoslowakei. Biologia Bratislava, (8): 615-61.

Kapanen M., 1979 - Nuoren sitruunavästäräkin Motacilla citreola määrittämisestä. Lintumies, 14: 111-116.

Kasparek M., 1992 - Die Vögel der Türkei: eine Übersicht. M. Kasparek Verlag, Heidelberg.

Keith S., Urban E. K. \& Fry C. H. (eds.), 1992 - The Birds of Africa. Vol 4. Academic Press, London, UK. 
Khaleghizadeh A., Roselaar K., Scott D. A., Tohidifar M., Mlíkovský J., Blair M. \& Kvartalnov P., 2017 - Birds of Iran: Annotated Checklist of the Species and Subspecies. Iranian Research Institute of Plant Protection.

Kinda V. V., Beskaravainy M. M., Dyadicheva E. L., Kostin S. Yu. \& Popenko V. M., 2003 - Ревизия редких, малоизученных и залетных видов воробьинообразных (Passeriformes) птиц в Крыму (Revision of rare, little study and flying species of Passeriformes birds in the Crimea). Бранта: сборник трудов Азово- Черноморской орнитологической станции Выпуск, 6: $25-58$.

Kirwan G. M., Boyla K., Castell P., Demirci B., Özen M., Welch H. \& Marlow T., 2008 - The birds of Turkey. Christopher Helm, London.

Kirwan G. M., Özen M., Ertuhan M. \& Atahan A., 2014 - Turkey Bird Report 2007-2011. Sandgrouse, 36: 146-175.

Knaus P. (ed.), 2018 - Atlante degli Uccelli Nidificanti in Svizzera 2013-2016: Distribuzione ed Evoluzione degli Effettivi degli Uccelli in Svizzera e nel Liechtenstein. Swiss Ornithological Institute, Sempach.

Koblik E. A. \& Arkhipov V. Yu., 2014 - Avifauna of the States of Northern Eurasia (former USSR): Checklists. Zoologicheskie Issledovania, 14.

Krüger T., Ludwig J., Pfützke S. \& Zang H., 2014 - Atlas der Brutvögel in Niedersachsen und Bremen 2005-2008. Naturschutz Landschaftspfl. Niedersachsen, Hannover, Heft 48.

Kruszewicz A. G., 2013 - Ptaki Polski. MULTICO Ofycina Widawni$c z a$, Warszawa.

Laur-Fournié P. \& Paris O., 2011 - Premier cas de nidification d'une Bergeronnette citrine Motacilla citreola en France. Ornithos, 18 (2): $136-138$

Lawicki Ł., 2014 - The Great White Egret in Europe: population increase and range expansion since 1980. British Birds, 107: 8-25.

Ławicki Ł. \& van den Berg A. B., 2019 - WP reports June to late July 2019. Dutch Birding, 41 (4): 260-276.

Lees A. C. \& Gilroy J. J., 2009 - Vagrancy Mechanisms in Passerines and Near-Passerines. In: Rare Birds, Where and When: An analysis of status and distribution in Britain and Ireland. Vol. 1. Sandgrouse to New World orioles. Slack R. (ed.). Rare Bird Books, York.

Lewington I., Alström P. \& Colston P., 1991 - A field guide to the rare birds of Britain and Europe. Harper Collins, London.

macaulaylibrary.org, 2020 - Motacilla citreola. <https://search. macaulaylibrary.org/catalog?taxonCode $=$ citwag \& $\mathrm{q}=$ Citrine $\% 20$ Wagtail\%20-\%20Motacilla\%20citreola> (retrieved in December 2020).

Maldonado C., Molina C. I., Zizka A., Persson C., Taylor C. M., Albán J., Chilquillo E., Rønsted N. \& Antonelli A., 2015 - Estimating species diversity and distribution in the era of Big Data: To what extent can we trust public databases? Species diversity and distribution in the era of Big Data. Global Ecology and Biogeography, 24 (8): 973-984

Malling Olsen K., 1990 - Fältbestämning av citronärla. Fåglar i Stockholmstrakten, 19: 137-148.

Matias R., Alfrey P., Crochet P.-A., Gonşalves A., Jara J., Mitchell D., Moore C. C., Muchaxo J., Santos J. L., Tavares J. T. \& Tipper R., 2012 - Rare Birds in Portugal. Portuguese Rarities Committee report for 2011. Anuário Ornitológico, 9: 3-56.

Matveyenko M. E., 1977 - Proceedings VII All-Union Ornithological Congress. Part I. Kiev: 84.

McGill A. R., 1963 - A Record of the Yellow-headed Wagtail for Australia. Emu, 63: 66-71.

Medenica I. \& Mirić R., 2015/2016 - Žutoglava pliska, Motacilla citreola, nova gnezdarica Balkanskog poluostrva. Ciconia, 24/25: 13-16.

Meissner W. \& Skakuj M., 1997 - First broods of the Citrine Wagtail Motacilla citreola in Poland and changes in the species breeding range in Europe. Notatki Ornitologiczne, 38: 51-60.

Mikkola H. J., 2014 - The Red-flanked Bluetail in Europe: range expansion and population trends A brief history of the Red-flanked Bluetail in Finland. British Birds, 107: 561-566.

Moore H. J. \& Boswell C., 1956 - Field observations on the birds of Iraq. Part II. Iraq Natural History Museum, Baghdad.
Morganti M., 2015 - Birds facing climate change: a qualitative model for the adaptive potential of migratory behaviour. Rivista Italiana di Ornitologia. Research in Ornithology, 85 (1): 3-13.

Mošanský L. \& Karaska D., 2002 - Trasochvost žltohlavý (Motacilla citreola). In: Rozšírenie vtákov na Slovensku. Danko Š., Darolová A. \& Krištín A. (eds.). VEDA, Bratislava.

Naumann J. F., 1897 - Naturgeschichte der Vögel Mitteleuropas. Vol. 3. Gera-Untermhaus, Köhler.

Netfugl.dk, 2020 - Citrine Wagtail (Motacilla citreola). $<$ https://www. netfugl.dk/dklist.php?id=species_info\&species_id=568> (retrieved on 12-05-2020)

Newton I., 2008 - The Migration Ecology of Birds. Academic Press, London.

Nielsen B. P., 1969 - Further Spring Observations on the Birds of Gilan, Northern Iran. Dansk Ornitologisk Forenings Tidssrift, 63 (1): 50-73.

Nikiforov M. Е., 2008 - Формирование и структура орнитофауны Беларуси (Formation and structure of the avifauna of Belarus). Белорус, Минск.

Nicoll M. J., 1919 - The birds of Egypt. Cairo Government Press, Cairo.

Observation.org, 2020 - Motacilla citreola. <https://observation.org/ species/239/> (retrieved in December 2020).

Occhiato D., 2011 - Black-backed Citrine Wagtail in Turkey - new to the Western Palearctic. Birding World, 24 (6): 257-261.

Ochapovsky V. S., 1965 - Пролет желтоголовой трясогузки Motacilla citreola werae на Кавказе (Passage of the yellow-headed wagtail Motacilla citreola werae in the Caucasus). Орнитология, 7: 483.

Olsen T. A., Bunes V., Egeland Ø., Gullberg A., Mjølsnes K. R. \& Tveit B. O., 2010 - Rapport fra Norsk sjeldenhetskomite for fugl (NSKF). Ornis Nirwegica, 33: 4-48.

Ornitho.it, 2020 - Cutrettola testagialla orientale. $<$ https://www.ornitho.it/> (retrieved in December 2020).

Peterson R. T., Mountfort G. \& Hollom P. A. D., 1954 - A Field Guide to the Birds of Britain and Europe. Collins, London.

Pétursson G. \& Dráinsson G., 1999 - Sjaldgæfir fuglar á Íslandi fyrir 1981. Náttúrufrceðistofnun Íslands., Fjölrit Náttúrufraðistofnunar, 37: 1-246.

Porter R. F. \& Aspinall S., 2010 - Birds of the Middle East. Christopher Helm, London.

Porter R. F., Salim M., Ararat K. \& Fadh O., 2010 - A Provisional Checklist of the Birds of Iraq el on behalf of Nature Iraq. Marsh Bulletin, 5 (1): 56-95.

Pyman G. A. \& the Rarity Records Committee, 1961 - Report on rare birds in Great Britain in 1960. British Birds, 54 (5): 173-200.

Ranner A., Laber J. \& Berg H.-M., 1995 - Nachweise seltener und bemerkenswerter Vogelarten in Österreich 1980-1990 1. Bericht der Avifaunistischen Kommission von Birdlife Österreich. Egretta, 38: 59-98.

Rasmussen P. \& Anderton J. C., 2012 - Birds of South Asia: The Ripley Guide. Lynx Edicions, Smithsonian Institution. Barcelona, Washington. Spain, USA. $2^{\text {nd }}$ edition.

Red'kin Y. A., 2020 - Желтоголовая трясогузка Motacilla citreola sensu lato Citrine Wagtail. In: Atlas of Breeding Birds of the European Part of Russia. Kalyakin M. V. \& Voltzit O. V. (eds.). Fiton $X X I$, Moscow: 558-560.

Red'kin Y. A. \& Kalyakin V. M., 2020 - Motacilla citreola Citrine Wagtail: 814-815. In: European Breeding Bird Atlas 2: Distribution, Abundance and Change. Keller V., Herrando S., Voříšek P., Franch M., Kipson M., Milanesi P., Martí D., Anton M., Klvaňová A., Kalyakin M. V., Bauer H.-G. \& Foppen R. P. B. (eds.). European Bird Census Council \& Lynx Edicions, Barcelona.

Salim M. A. \& Porter R. F., 2015 - The Ornithological Importance of the Southern Marshes of Iraq. Marsh Bulletin, 10 (1): 1-24.

Salim M. A., Al-Sheikhly O. F., Majeed K. A. \& Porter R. F., 2012 - An annotated checklist of the birds of Iraq. Sandgrouse 34 (1): 4-43.

Sándor A. D., Moldován I. \& Bugariu S., 2007 - First breeding record of the Citrine Wagtail (Motacilla citreola) in Romania. Scientific Annals of the Danube Delta Institute, 13: 107-110.

Schelper W., 1973 - Eine Zitronenstelze (Motacilla citreola Pall.) in Südniedersachsen. Vogelkundliche Berichte aus Niedersachsen, 5: 46-47. 
Schepers F. J., Keijl G. O., Meininger P. L. \& Rigoulot J. B., 1998 Oiseaux d'eau dans le Delta du Sine-Saloum et la Petit Côte, Sénégal, Janvier 1997. WIWO-report 63. WIWO, Zeist.

Schmitz M., 1998 - Regelmassiger Frühjahrszug der Zitronensteltze Motacilla citreola an der westlichen Schwarzmeerküste. Vogelwelt, 119: 323-327.

Schollaert V., 1998 - Citrine Wagtail, Motacill citreola, in Ethiopia and its status in Africa. Bulletin African Bird Club, 5 (2): 129-130.

Ściborska M., 2004 - Breeding biology of the Citrine Wagtail (Motacilla citreola) in the Gdansk region (N Poland). Journal of Ornithology, 145: 41-47.

Scott D. A. \& Carp E., 1982 - A midwinter survey of wetlands in Mesopotamia, Iraq: 1979. Sandgrouse, 4: 60-76.

Sharrock J. T. R. \& Sharrock E. M., 1976 - Rare Birds in Britain and Ireland (1976). $T \& A D$ Poyser Ltd, Berkhamsted.

Shirihai H., 1996 - The Birds of Israel. Academic Press, London, UK.

Shirihai H. \& Svensson L., 2018 - Handbook of Western Palearctic Birds. Vol. 1. Passerines: Larks to Warblers. Helm, Bloomsbury Publishing Plc, London, UK.

Skerrett A., 2001 - European Bee-eater Merops apiaster and Citrine Wagtail Motacilla citreola: the first records for Seychelles. Bulletin African Bird Club, 8 (1): 51-53.

smartbirds.org, 2020 - Motacilla citreola. <https://smartbirds.org/> (retrieved in November 2020).

Smith F. R. \& the Rarities Committee, 1968 - Report on rare birds in Great Britain in 1967. British Birds, 61 (8): 329-65.

Smith F. R. \& the Rarities Committee, 1969 - Report on rare birds in Great Britain in 1968. British Birds, 62 (11): 457-92.

Smith F. R. \& the Rarities Committee, 1970 - Report on rare birds in Great Britain in 1969. British Birds, 63 (7): 267-93.

Snow D. \& Perrins C., 1998 - The Birds of the Western Palearctic. Concise Edition. Vol. 2. Oxford University Press, Oxford.

Studecky J., 2021 - Pallid Harrier breeding near Dobrichov, Czechia, in 2020. Dutch Birding, 43: 141-144.

Sudfeldt C., Bairlein F., Dröschmeister R., König C., Langgemach T. \& Wahl J., 2012 - Vögel in Deutschland 2012. Dachverbandes Deutscher Avifaunisten, Bundesamtes für Naturschutz, Länderarbeitsgemeinschaft der Vogelschutzwarten, Münster.

Sudfeldt C., Dröschmeister R., Frederking W., Gedeon K., Gerlach B., Grüneberg C., Karthäuser J., Langgemach T., Schuster B., Trautmann S. \& Wahl J., 2013 - Vögel in Deutschland 2013. Dachverbandes Deutscher Avifaunisten, Bundesamtes für Naturschutz, Länderarbeitsgemeinschaft der Vogelschutzwarten, Münster.

Sushkin P. P., 1892 - Птицы Тульской губернии (Birds of the Tula province). Материалы к познанию фауны и флоры Российской империи, 1: 1-105.

Svensson L., 1977 - Problemet att skilja ung citronärla Motacilla citreola från andra ärlearter. Vår Fågelvärld, 36: 48-52.

Swaine C. M. \& the Rarities Committee, 1962 - Report on rare birds in Great Britain in 1961. British Birds, 55 (12): 562-84.

Terraube J., 2020 - Circus Macrourus Pallid Harrier. In: European Breeding Bird Atlas 2. Distribution, Abundance and Change. Keller V., Herrando S., Voříšek P., Franch M., Kipson M., Milanesi P., Martí D., Anton M., Klvaňová A., Kalyakin M. V., Bauer H.-G. \& Foppen R. P. B. (eds.). European Bird Census Council \& Lynx Edicions, Barcelona: 462-463.

Terraube J., Mougeout F. Auvinen A-P. \& Arroyo B., 2021 - Pallid Harrier Circus Macrourus. In: Migration Strategies of Birds of Prey in Western Palearctic. Panuccio M., Mellone U. \& Agostini N. (eds.). CRC Press, Boca Raton, Florida: 146-151.

Toochin R., 2019 - First record of Citrine Wagtail (Motacilla citreola) for British Columbia and Canada. In: E-Fauna BC: Electronic Atlas of the Fauna of British Columbia. Klinkenberg B. (ed.). Lab for Advanced Spatial Analysis, Department of Geography, University of British Columbia, Vancouver. <efauna.bc.ca> (Accessed: 202103-23 2:31:57 AM).

Tyler S. J. \& Kirwan G. M., 2020 - Citrine Wagtail (Motacilla citreola). In: Handbook of the Birds of the World Alive. del Hoyo J., Elliott A., Sargatal J., Christie D. A. \& de Juana E. (eds.). Lynx Edicions, Barcelona. $<$ https://www.hbw.com/node/57827> (retrieved on 294-2020).
Underhill L. G., 2015 - Four records of Citrine Wagtail Motacilla citreola in South Africa: the bigger picture. Ornithological Observations, 6: 65-67.

Vauk G., 1964 - Ergebnisse einer Ornithologischen Arbeitreise an den Beyşehir Gölü. Beitraege Vogelkunde, 19 (4): 225-260.

Vaurie C., 1959 - The Birds of the Palearctic Fauna. Passeriformes. H.F. \& G. Whitherby, London.

Vinicombe K. \& Cottridge D., 1996 - Rare birds in Britain and Ireland a photographic record. Collins, London.

Wahl J., Dröschmeister R., Langgemach T. \& Sudfeldt C., 2011 - Vögel in Deutschland 2011. Dachverbandes Deutscher Avifaunisten, Bundesamtes für Naturschutz, Länderarbeitsgemeinschaft der Vogelschutzwarten, Münster.

Wallace D. I. M., 1982 - Observations on Migrant Birds at Azraq in North-east Jordan, up to April 1967. Sandgrouse, 4: 77-99.

Wardlaw-Ramsay R. G., 1923 - Guide to the Birds of Europe and North Africa. Gurney and Jackson, London.

Wester J., 1998 - Bird Travel Report: Syria 13/2 - 5/3 and Jordan 6/319/3 1998. <https://osme.org/trip-reports/syria1> (retrieved in June 2020).

Wielstra M., Fijen T., van Bemmelen R., Gobin S. \& van der Spek V., 2019 - Citrine Wagtail calls: can ssp. be identified based on calls? $<$ https://www.turnstones.org/citrine-wagtail-calls-of-ssp $>$

Wilk T., Kajtoch Ł. \& Bielański W., 2009 - The third record of breeding Citrine Wagtail (Motacilla citreola) in Slovakia. Tichodroma, 21: 96-98.

Williamson K., 1982 - Citrine Wagtails on Fair Isle. In: Birds new to Britain and Ireland. Sharrock J. T. R. \& Grant P. J. (eds.). T. \& $A$. D. Poyser: 51-54.

Wilson M., 1979 - Further range expansion by Citrine Wagtail. British Birds, 72: 42-43.

Zarei F., Hosseini S. N., Hussein R. H., Pezeshk J., Rahim M. \& Maleki L., 2018 - The Birds of Kurdistan Province, western Iran. Journal of Threatened Taxa, 10 (14): 12859-12906.

\section{SUPPORTING INFORMATION / INFORMAZIONI SUPPLEMENTARI}

Additional Supporting Information may be found online for this article. Per questo articolo sono disponibili informazioni supplementari online.

S1 - Consulted bibliography 